\title{
How StABle Is ChinA's GROWTH? SHEDDING Light ON SPARSE DATA
}

\author{
Hunter Clark, Jeff Dawson, and Maxim Pinkovskiy
}

\section{OVERVIEW}

- China faces skepticism about the accuracy of its GDP growth statistics, fueled by incidents of data falsification, secrecy around methodological processes, and press censorship, especially during periods of economic stress.

- Against this backdrop, the authors present alternative indicators for measuring China's business cycles using variables that are closely related to China's "true" economic growth, but unlikely to be subject to manipulation.

- Those proxies, which employ index- and factor-based statistical methodologies and data on nighttime lights usage, production, trade, investment, and credit, suggest that China's economic growth has been more volatile in recent years than is portrayed in the official GDP statistics.

- These fluctuations have occurred around a trend growth rate that has been slowing and that is likely to slow substantially in coming years.
7 here is widespread agreement among both market participants and China's policymakers that China's economic growth slowed in 2018. However, there is much less consensus on the magnitude of the slowdown and even on when it started. Similar disagreements over the magnitude and timing of Chinese business cycles have occurred periodically since at least the early 1990s. In contrast to earlier years, these issues are now of major importance for policymakers in other large economies because China's role in the global economy has increased dramatically. Indeed, on the eve of China's accession to the World Trade Organization (WTO) in 2001, China accounted for 3.6 percent and 7.3 percent of global GDP and merchandise trade, respectively. Those shares have now increased to 16 percent and 23.8 percent as China has become the world's second largest economy and largest trading country. Moreover, China plays a dominant role in world demand for many key energy, metal, and agricultural commodities, and possesses one of the world's largest financial systems, which is poised to become more globally integrated as its domestic markets gain inclusion in important global benchmark indexes (Sin 2019).

\footnotetext{
Hunter Clark is an assistant vice president, Jeff Dawson a research officer, and Maxim Pinkovskiy a senior economist at the Federal Reserve Bank of New York. Email: hunter.clark@ny.frb.org; jeff.dawson@ny.frb.org; maxim.pinkovskiy@ny.frb.org.

The views expressed in this article are those of the authors and do not necessarily reflect the position of the Federal Reserve Bank of New York or the Federal Reserve System. To view the authors' disclosure statements, visit https://www.newyorkfed.org/research/ epr/2020/epr_2020_china-lights_clark.html.
} 
Disagreements on China's business cycle stem from differing views on the reliability and accuracy of China's official economic statistics and on differing approaches to addressing perceived shortcomings in the official data. In this article, we seek to add some alternative indicators to policymakers' toolbox for measuring China's cyclical fluctuations, which, in turn, can be used as inputs for making relevant policy decisions. In contrast to much of the previous academic literature, we focus almost exclusively on relatively high-frequency (monthly) indicators of changes in China's growth rate, as opposed to growth-rate levels. However, we offer some observations on what the indicators say about cyclical fluctuations in longer-term trend growth.

We group our alternative indicators into two buckets. The first revolves around satellite nighttime lights (NTL), based on a methodology described in Clark, Pinkovskiy, and Sala-iMartin (2020). That article focused on growth-rate levels through the fourth quarter of 2015 and found no convincing evidence that the growth rate at the end of 2015 had been slower than officially reported, though it was noted that there was evidence that the change in the growth rate (marking a slowdown) had been more than reported. In this article, we focus entirely on the changes in growth, at monthly frequency from 2001 or 2006 (depending on data availability) through the middle of 2019. The second set of indicators we refer to as "factor based." This includes an indicator based on principal component analysis (PCA) and a novel approach using sparse partial least squares regression (SPLS), which is discussed in detail in a companion article in this special issue (Groen and Nattinger 2020).

Our results suggest that China's economic growth has been more volatile over the past five years than portrayed in the official GDP statistics. By our measures, growth slowed by substantially more than reported over the course of 2014 and 2015 and then staged a rebound in 2016, to peak in early 2017, a pattern that was scarcely evident in the official data. During the most recent cycle, growth slowed beginning in 2017, but may have been more stable in 2018 and the first half of 2019 than portrayed in the financial press at the time. Our analysis also suggests that cyclical growth upturns (accelerations) have become significantly shorter-lived in the period after the global financial crisis, while growth slowdowns have become much longer. These fluctuations have occurred around a trend growth rate that has been slowing, and which is likely to slow substantially in coming years.

The rest of this article is organized as follows: Section 1 provides some background on long-standing controversies over the accuracy of China's GDP data. Section 2 provides a high-level overview of methodologies most frequently employed to calculate alternative growth indicators, and then introduces the methods used in this article. Section 3 discusses the results, focusing on what they say about the contours of China's business cycle and growth performance since the beginning of 2014. Section 4 broadens the focus to how the alternative indicators correlate with global data and provides additional analysis focused on which alternative indicators provide the best fit to the global data. Section 5 takes a longer-term view on the cyclical fluctuations around China's longer-term trend. Section 6 concludes. The appendixes provide details on the satellite nighttime light methodology used in two of our alternative indicators and the data employed in our analysis. 


\section{China Faces Perennial Questions over the Reliability AND ACCURACy of ITS DATA}

During 2018 and up through the beginning of 2019, the financial press was awash with sometimes conflicting stories on China's economic performance, ranging from pessimistic to sanguine. On the more pessimistic side were those arguing that China's growth was much weaker than reported, by some accounts less than half of the official figure (Shane 2019; Pettis 2019). On the more sanguine side were views that the economy had slowed only modestly and was poised for a near-term rebound (Rothman 2019). In 2018, China's own official growth statistics showed only a small decrease in the four-quarter growth rate, from 6.7 percent at the end of 2017 to 6.4 percent at the end of 2018, and the decrease occurred entirely in the last two quarters of the year. That translated to official growth slowing only marginally, having ended 2016 at 6.8 percent (Chart 1$)$.

The fundamental reasons for the wide range of views revolve around long-standing skepticism about the accuracy of the official statistics. Indeed, market participants have raised questions about the official data for many years, including during 1998-2000 (the Asian financial crisis), 2003-04 (the severe acute respiratory syndrome crisis), 2008-09 (the global financial crisis), and 2015-16 (China's currency and equity market stress). Uncertainty about the data has been fueled by well-publicized instances of falsification of data at the local level, nontransparency and secrecy around methodological processes, including but not limited to price deflators, limited independence of the statistical authorities, and censorship of the domestic financial press, especially during periods of economic stress (Holz 2013; Wu 2014; Wee and Yuan 2018). In the eyes of many critics, the remarkably low, and declining, volatility of China's growth rate also appears implausible (Chart 2).

There is an expansive academic literature on the accuracy of China's official data. These studies most often focus on relatively low-frequency data-for example, annual data-as opposed to the intra-year business cycle that we primarily focus on in this article. ${ }^{1}$ Of direct relevance to this article, Clark, Pinkovskiy, and Sala-i-Martin $(2017 ; 2020)$ used satellite nighttime lights to estimate quarterly growth rates from 2004 to 2015. The results in that analysis suggest that growth-rate levels were lower than reported in the years prior to the global financial crisis, but usually higher than reported thereafter. The authors also found that growth had a shallower decline in 2008 and a stronger recovery in 2009 than reported, and a steeper decline than reported during 2014 and 2015. That analysis did not find convincing evidence that growth was weaker than reported in the final quarter of 2015.

\section{Using Alternative Growth Indicators to Gauge The Business CyCle in China}

Against a backdrop of doubt surrounding official statistics, there is a long history among market participants, policymakers, and academic researchers of using alternative indicators as proxies for the business cycle in China. In this article, we hope to add to the array of such indicators. Our approach is to select variables that are closely related to China's "true" economic growth, but that are either reported independently of China's statistical system, 
Chart 1

China's Official GDP Growth Rate

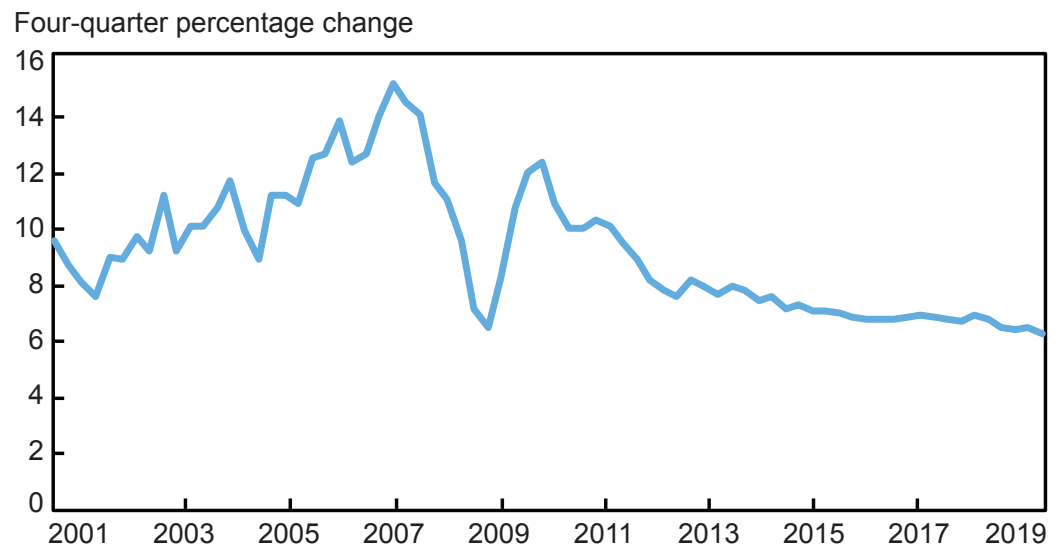

Sources: National Bureau of Statistics of China and national authorities via CEIC Data and Haver Analytics; authors' calculations.

\section{Chart 2}

China's GDP Volatility versus That of Other Countries

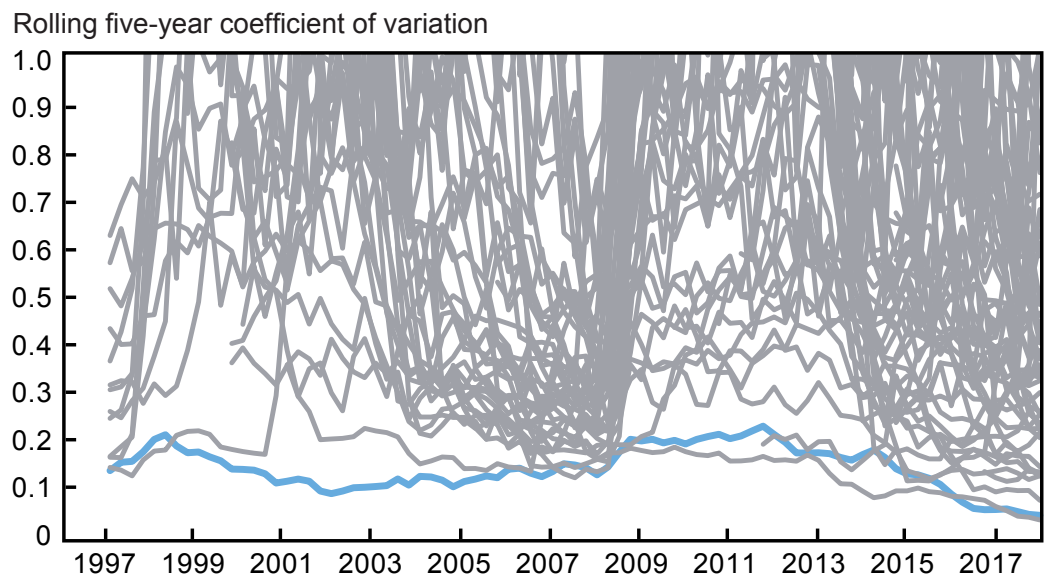

Sources: National Bureau of Statistics of China and national authorities via CEIC Data and Haver Analytics; authors' calculations.

Notes: The gray lines show the GDP volatility of seventy-eight other countries. The coefficient of variation is calculated as the ratio of the rolling five-year standard deviation of the four-quarter GDP growth rate to the absolute value of the rolling five-year compounded quarterly annualized growth rate. The vertical axis is cropped at 1. Data are through the second quarter of 2018. 
or cover such a wide range of variables that they are unlikely to be subject to much manipulation or "smoothing." Our focus is on constructing relatively high-frequency indicators that can be updated fairly easily, so as to be useful in real-time policy analysis.

Alternative indicators in the literature - both academic and market-analyst - tend to group into two categories: direct adjustment of official data and index-based approaches, typically involving various econometric techniques. One line of analysis among the direct-adjustment methods computes alternative deflators for GDP, which are then typically applied to nominal GDP to obtain the measure in real terms (Keidel 2001; Kerola 2018). Another line of direct-adjustment analysis works "bottom up" from a detailed sectoral level, often relying heavily on data oriented around the industrial sector within GDP (Wu 2014; Reserve Bank of Australia 2015; Wigram Capital Advisors 2019; Chen et al. 2019). All of these direct-adjustment methods yield results that suggest that GDP growth sometimes differs substantially from officially reported levels, and has usually been lower than reported since the global financial crisis. However, the direct-adjustment methods are quite difficult to implement on a high-frequency basis without making strong simplifying assumptions that themselves may not be plausible.

Among the index-based approaches, the simplest, and possibly the best known in recent years, is the so-called "Li Keqiang index," which is named after China's premier and second-ranking member of the Politburo Standing Committee of the Communist Party. The index gets its inspiration from WikiLeaks' publication of remarks made by Premier Li in 2007 (then still a provincial party secretary) to the effect that he tracked economic activity in his province by monitoring electricity, bank loans, and rail freight. This index is frequently implemented as a simple average of the three indicators. Chart 3 shows an example of this index - computed as a simple average-and each of its components. A sample of other statistical approaches can be found in Clark, Pinkovskiy, and Sala-i-Martin (2017).

Our own alternative indicators follow the index-based statistical methodologies. Our first approach uses indexes computed from a satellite nighttime lights (NTL) methodology (Clark, Pinkovskiy, and Sala-i-Martin 2017; 2020). Appendix 1 to this article covers the details of this approach, and the interested reader can find further information in the studies cited. It is well-established that lights are strongly correlated with measures of economic activity, such as national accounts GDP, in levels and growth rates (Henderson, Storeygard, and Weil 2012). In broad-brush terms, our methodology uses satellite-recorded nighttime lights to aggregate multiple indicators of economic activity into a best unbiased linear predictor of the underlying unobserved true income process.

As discussed in Appendix 1, we exploit variations of provincial growth within China to calculate weights for our indexes. We calculate two sets of NTL-based indicators, which we refer to as "NTL-Narrow" and "NTL-Broad." The NTL-Narrow index comprises the "Li Keqiang" variables mentioned above as well as GDP itself, while the NTL-Broad index comprises those variables covered by Fernald, Hsu, and Spiegel (2015) that are available at the provincial level, including electricity, rail freight, loans, retail sales, floor space construction newly started, real estate investment, air passenger traffic, and exports. As discussed in Appendix 2, in order to operationalize these indicators for policy work, we make an important modification to their composition, substituting M2 for loans in constructing both the NTL-Narrow and NTL-Broad indexes. We make this substitution to be a bit more conservative in how we capture credit conditions in our model, as the relative stability of loan growth does not adequately reflect the on-again, off-again tightening of government policy over the "shadow finance" sector. ${ }^{2}$ 
Chart 3

Rail Freight, Loans, Electricity, and the "Li Keqiang" Index

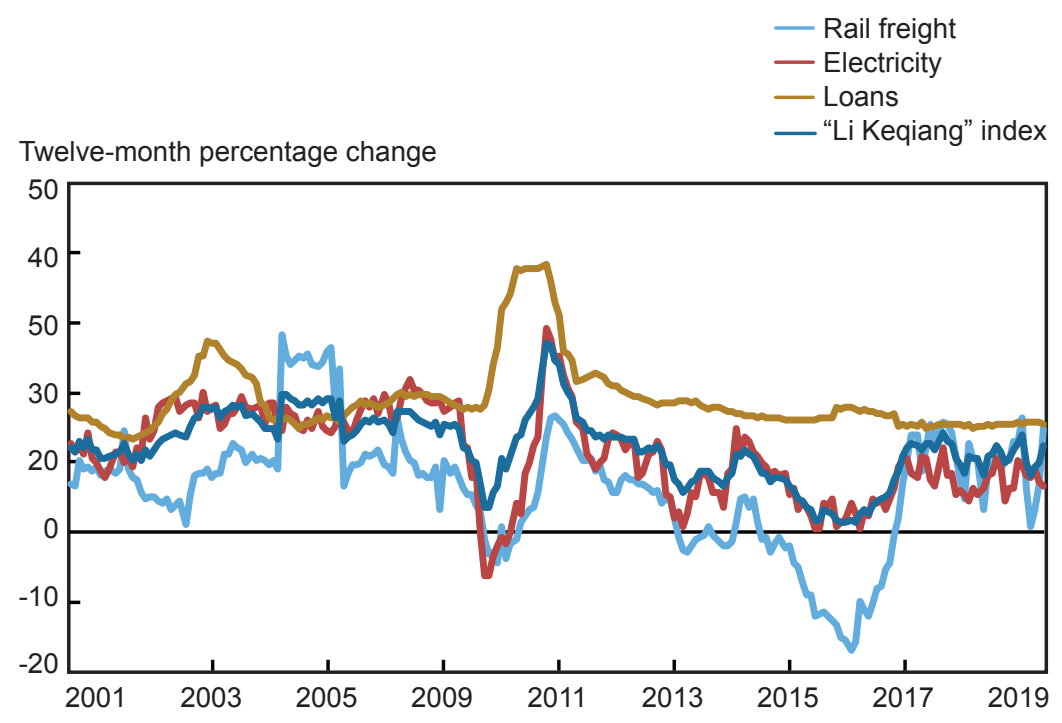

Sources: National Bureau of Statistics of China via CEIC Data; authors' calculations.

The predicted growth rates for the NTL proxies are calculated in a three-step process. First, weighted indexes are constructed using national-level variables, in which the weights are derived from the provincial nighttime lights regressions mentioned above. Then, a constant and a regression coefficient are calculated for each index by regressing official quarterly GDP on them through the end of $2013 .^{3}$ In the final step, we use the changes in the out-of-sample predicted values from the beginning of 2014 onward as our alternative indicator.

Our second set of approaches revolves around what we refer to as "factor-based" methods. The first of these, labeled PCA in the charts and tables that follow, is calculated from the first principal component of the twelve-month (log) percentage change in a very wide range of variables of a data sample that begins in April 2005 (see the table in Appendix 2). ${ }^{4}$ The sixty-two variables we choose range from production and trade to investment and credit. For all variables except the purchasing managers' indexes (PMIs), we take the log year-over-year difference in seasonally adjusted data. In order to account for structural shifts in the data, we first detrend the data using a biweight filter (Stock and Watson 2012). We then normalize the data so that the mean and standard deviation of each series are equal to zero and one, respectively. In order to scale this index to units of official GDP, we regress the detrended year-over-year (log) percentage change growth rates of Chinese GDP on our principal component, excluding all data after 2013, and then add the trend from official GDP back into the calculation of predicted GDP growth.

The second factor-based approach is labeled "SPLS" and uses sparse partial least squares regression techniques. This methodology is covered in detail in a companion article (Groen and Nattinger 2020). Broadly, this method extracts a set of common factors, via partial least 
squares regression, that best reflects the correlations between a set of economic activity proxy variables - which can be thought of as "training variables" - and a wider set of candidate data. The "sparse" component of the methodology refers to the technique by which this wider range of candidate data is first narrowed to a subset that has relatively strong individual correlations with the proxy variables, so as to reduce the risk that noisy variables create "weak" or "near-strong" factors.

In the first instance, the SPLS method is trained on Chinese real imports from the United States, Japan, and the European Union, reported by the exporting countries' statistical agencies as exports to China and Hong Kong. This approach follows Fernald, Hsu, and Spiegel (2015; 2019) and is similarly motivated by the assumptions that China's imports are closely related to its true growth and that exporting countries' statistics should not be influenced by China's domestic statistical problems. On further refinement, the SPLS indicator used in this article is trained on China's imports (as reported by exporting countries), a diffusion index of the twelve-month change in a wide range of gross industrial production values in physical units (covering about 118 industries at present), and Chinese retail sales. ${ }^{5}$

\section{China's Economic Performance over the Past Two CyCles}

Following the methods discussed in the previous section, we have four alternative indicators, two of which are factor-based-the PCA and SPLS indicators-and two of which are nighttime-lights-based-NTL-Narrow and NTL-Broad. In many of the tables and charts that follow, we will average the PCA and SPLS indicators and refer to this indicator as the "Average Factor"; similarly, we will average all four indicators and label the result the "Average Alternative."

First, we examine what these alternatives say about China's business cycle over the history of the respective series. Charts 4 and 5 plot the Average Alternative indicator against official GDP and China's imports from the United States, Japan, and the European Union (as reported by the trading partners), all normalized and at a monthly frequency. Chart 6 plots the four alternatives separately.

On the whole, official GDP tracks the alternative indicators, but with clear deviations. For example, official growth generally is higher than the Average Alternative in the first half of the 2000s, and the downturn during and subsequent rebound after the global financial crisis are shallower and stronger, respectively. ${ }^{6}$ The official and alternative indicators of growth track each other quite closely in the aftermath of the global financial crisis until 2013, when the official figures become much smoother. It is thus readily apparent that the alternative indicators show more cyclical variation in growth than has been reported in official GDP over at least the past five years. By contrast, the alternatives correlate quite well with China's imports over the same period, as they had in the past. This provides visual evidence that the alternative indicators are plausible indicators of China's true growth, and perhaps more so than official GDP growth in recent years.

We now turn to what these alternatives say about China's GDP growth. We will focus on relative changes in growth rates in terms of units of official GDP. The reason for this is that we cannot identify the "true" growth rate under any of our methodologies, since it is unobserved. 
Chart 4

Official GDP and the Average Alternative

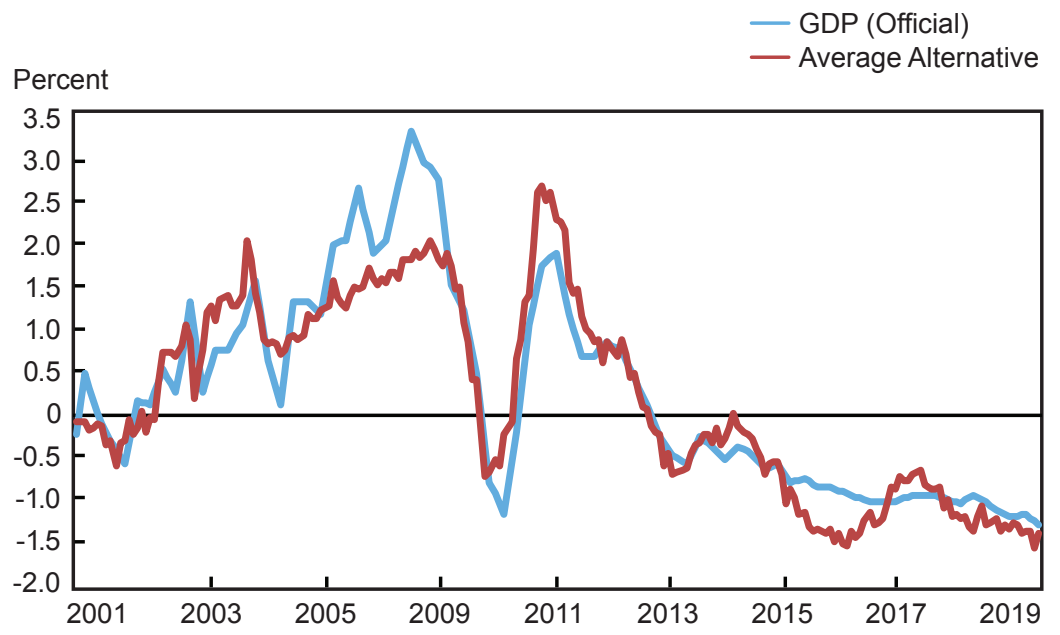

Sources: National Bureau of Statistics of China via CEIC Data; authors' calculations.

Notes: The Average Alternative is the average of two nighttime-lights-based indicators and two factor-based indicators, as described in the text. All data are computed from a twelve-month log difference of seasonally adjusted monthly data, with monthly GDP linearly interpolated from quarterly data. The data are monthly and normalized with a mean of 0 and a standard deviation of 1 .

CHART 5

China's Imports and the Average Alternative

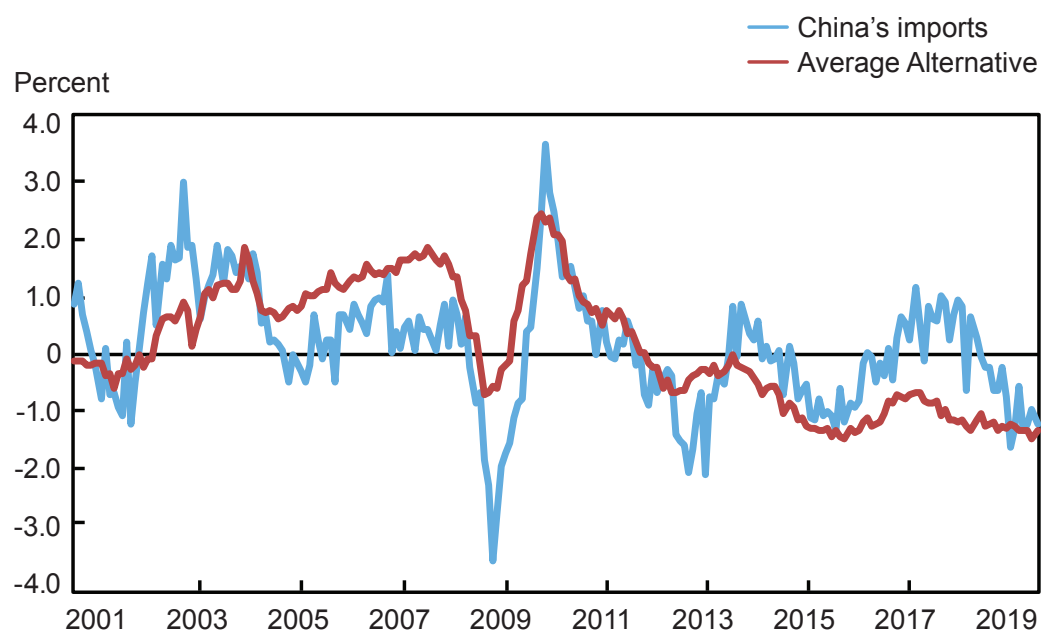

Sources: National Bureau of Statistics of China via CEIC Data; authors' calculations.

Notes: China's imports are as reported by exporting countries. The Average Alternative is calculated from two nighttime-lights-based indicators and two factor-based indicators, as described in the text. All data are computed from a twelve-month log difference of seasonally adjusted monthly data. 
However, we can make comparisons of the values of our alternative growth indicators over periods of time. Put another way, we can make statements such as "Chinese growth in the fourth quarter of 2018 was higher than that in the same period of 2015," or "the decline in Chinese growth through the second quarter of 2019 has been smaller than the decline in Chinese growth during 2015," without relying on any scaling assumptions.

We have chosen to measure changes in growth rates relative to the end of 2013. This starting period coincides with the starting point of our out-of-sample regressions in the previous sections. Moreover, this period encompasses a number of seemingly significant macroeconomic shocks that one would expect, a priori, to affect GDP growth performance. For example, from 2014 through early 2016, China experienced a major property-sector slump and recovery, a stock market boom and bust, large capital outflows, sales of foreign exchange reserves, and exchange-rate volatility, and large policy-driven fluctuations in credit. Throughout this period, market participants were acutely concerned about "hard landing"-a large and abrupt growth slowdown - in China. Similarly, after 2016, the Chinese government initiated a tightening of financial and fiscal conditions in order to reduce financial vulnerabilities, but was buffeted by trade tensions and volatility of domestic equity markets and shifted again to a loosening of macroeconomic policies. Market participants remained highly attuned to "hard landing" risks, albeit perhaps not to the same degree as in the earlier period.

Chart 7 plots the change in official growth implied from the Average Alternative and the official growth rate itself. There is little correlation between official growth and the alternative, at least until the middle of 2018, after which the two measures become more similar. The alternative shows a downturn that bottomed at the end of 2015 , followed by a rebound that peaked in early 2017, and then another downturn. The more recent downturn appears to have occurred mainly in 2017; growth in 2018 slowed comparably little for the year as a whole, as it rebounded a bit in the first half of the year but turned down again in the second half. Growth in the first half of 2019 was quite stable aside from a temporary downward spike in May, according to the alternative measure.

During the downward cycle through the end of 2015, the Average Alternative suggests that growth fell by almost 2 percentage points, approximately double the slowdown that was shown in the official statistics. Growth then is estimated to have rebounded by a bit over 1 percentage point using the alternative methodology, versus approximately zero change in the official data. The most recent slowdown through the end of 2018 measures a bit over 1 percentage point, more than double the slowdown in the official statistics. This decline cumulates to 1.2 percentage points by the second quarter of 2019, still about double the official slowdown. Interestingly, the change in growth rates in the final two quarters of 2018 through the first two quarters of 2019 is quite close in the official data and in the Average Alternative, suggesting that the official figures may have been more accurate since the middle of 2018.

The cyclical pattern shown in the alternative indicators appears to be consistent with the "story" told by credit and industrial production in China. Chart 8 plots China's aggregate credit growth and "credit impulse" against the average of our alternative growth indicators. Credit growth is simply the percentage change in the stock of aggregate credit, while the credit impulse follows Biggs, Mayer, and Pick (2009) and is defined as the change in the flow of aggregate credit $-\Delta(\Delta D(t))$ - relative to GDP. The correlation between the credit cycle and our alternative indicators is a reassuring robustness check on the usefulness of the alternatives as cyclical indicators. China's economy is highly investment-intensive and credit-driven, and 
CHART 6

Alternative Indicators for China's GDP Growth
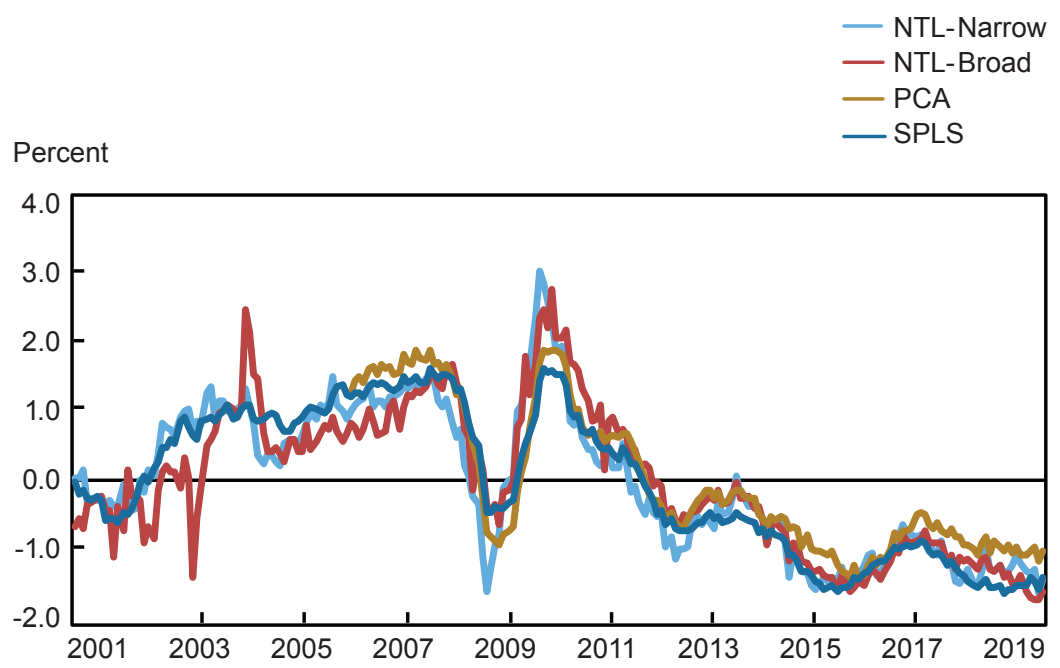

Sources: National Bureau of Statistics of China via CEIC Data; authors' calculations.

Notes: NTL is nighttime lights. PCA is principal component analysis. SPLS is sparse partial least squares. All data are computed from a twelve-month log difference of seasonally adjusted monthly data, with monthly GDP linearly interpolated from quarterly data. They are monthly and normalized with a mean of 0 and a standard deviation of 1.

\section{Chart 7}

Change in Official and Alternative GDP Growth

Cumulative difference relative to December 2013

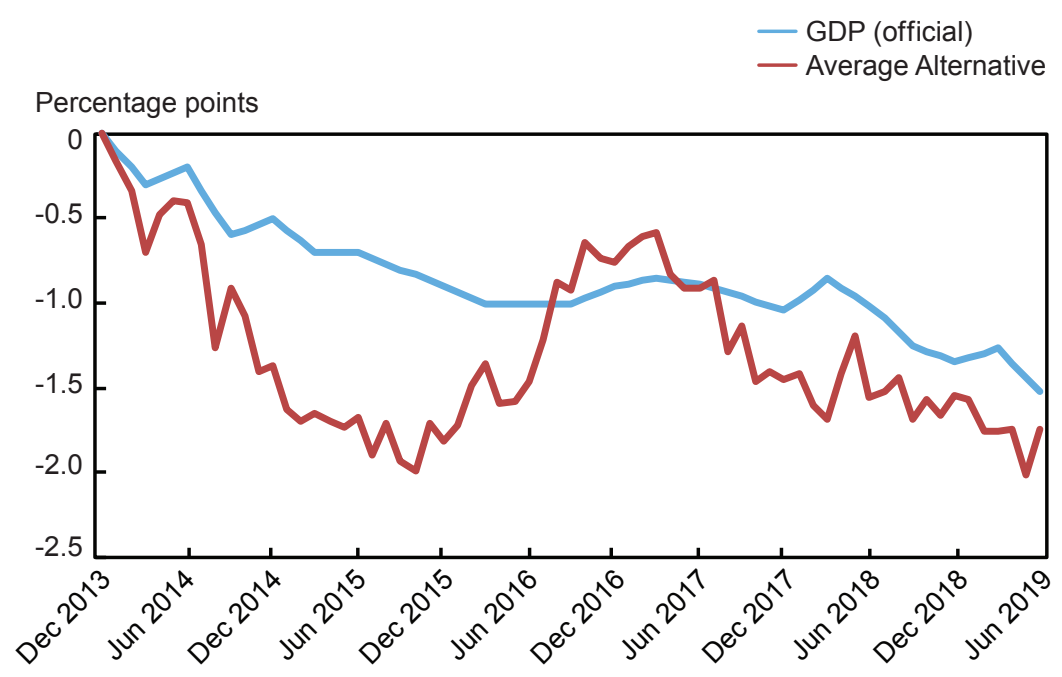

Sources: National Bureau of Statistics of China via CEIC Data; authors' calculations. 
against such a backdrop, one should expect to see a strong correlation between credit availability and growth. It is interesting to note that the upturn in the credit impulse in early 2019 coincides with very little change in growth momentum as proxied by the Average Alternative indicator. This attenuated response might reflect impairments to the credit intermediation process, such as tight credit conditions for China's private sector and other sectors reliant on nonloan financing channels as well as external headwinds from U.S. tariffs.

Next we move to industrial production. This variable is important because industry remains by far China's single largest sector as a share of GDP. This share has held fairly steady at about one-third of GDP since 2015, somewhat lower than an average 40.6 percent of GDP during 2000-10. Chart 9 plots the twelve-month percentage change and a rolling three-month percentage change (seasonally adjusted at an annual rate). The illustration shows that industrial production growth hit a low in 2015, recovered by about 2.5 percentage points by May 2017, and then slowed again. The latest business cycle slowdown occurred in two phases: the first in 2017 , followed by a partial recovery in early 2018 , and then a further slowdown in the second half of 2018. The total slowdown in the recent cycle through the end of 2018 measured about 2.1 percentage points, with growth still above the low point in 2015. Interestingly, industrial production accelerated noticeably in early 2019, but this was driven by very strong monthly readings in March and June that apparently did not coincide with a sustained upturn in economic activity.

Finally, the picture painted by the alternatives is consistent with the macroeconomic policy stance in China. The rebound in the economy from the low point of the 2014-15 cycle was primarily driven by an easing of macroprudential policies in the housing sector and a de facto loosening of fiscal policy at the local government level. As early as May 2016, statements in the government-controlled press attributed to an anonymous senior official signaled a potential shift toward tighter macroeconomic policies (Murray 2016; Zhang 2017), which were followed over the remainder of 2016 by various reforms to control risks in the financial sector. By February 2017, China's leader, Xi Jinping, was quoted in the official press as ordering that local and central government authorities "unswervingly" crack down on financial irregularities (Wu 2017), a directive that was followed in later months by monetary tightening, increasingly stringent macroprudential policies in the financial sector, and tighter restrictions on local government borrowing. By the beginning of 2018, policy had begun to loosen again, as the People's Bank of China implemented a cut to required reserve ratios in January and initiated substantial reductions in market-determined interest rates. The shift toward looser policies was formally acknowledged in a Politburo communique in April 2018 (Zhang 2018), though the authorities continued to rein in riskier types of "shadow finance" lending. ${ }^{7}$ The renewed deceleration of growth in the latter part of 2018 coincided with increasingly large declines in shadow finance and in intensification of the trade conflict with the United States. 
Chart 8

The Credit Cycle and a Growth Proxy

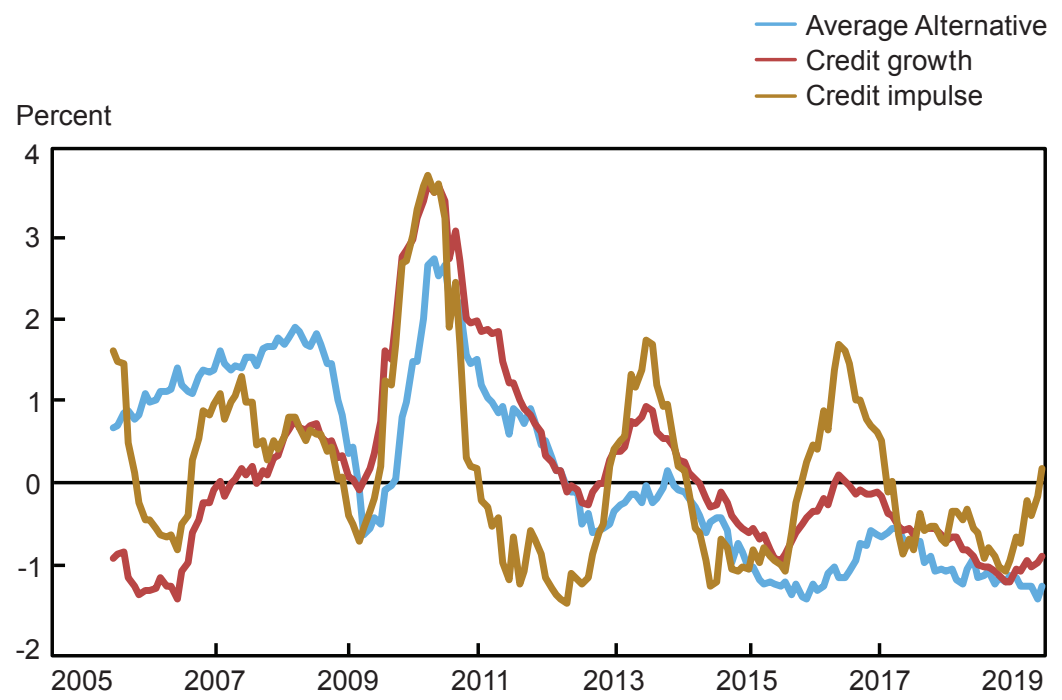

Sources: People's Bank of China via CEIC Data; authors' calculations.

Note: Credit growth and credit impulse are pulled forward by four months.

\section{Global Data Correlate with Alternative Indicators}

We next turn to how the alternative indicators correlate with a wider set of variables, including indicators of activity outside of China. Again, the basic idea is that unobserved true growth of the Chinese economy manifests itself through variables that are measured outside of the Chinese statistical system. The most direct proxy used here is real Chinese imports (as independently reported by exporting countries); we also examine global commodity prices and foreign countries' industrial production and manufacturing surveys. ${ }^{8}$

Table 1 shows the results from simple regressions of monthly data on China's imports, commodity prices, and foreign-country manufacturing activity. ${ }^{9}$ For each dependent variable, the table shows the results of a regression on China's official GDP, followed by the results of the same regression on the Average Alternative. (Appendix Table 3A plots the same information but breaks out detail for the NTL-Narrow, the NTL-Broad, the Average Factor, and the Average Alternative.) The data are normalized with a mean equal to zero and a standard deviation equal to one; the table shows Newey-West $t$-statistics, adjusted R2, and the root-mean-square errors (RMSEs) of the regressions. The three sets of columns show results from regressions over 2001-13, 2014-18, and then 2014 through June 2019. The regressions involving imports also factor in China's real effective exchange rate, which is not shown in the table, while the others are simple bivariate regressions. ${ }^{10}$

The table illustrates that over the earliest period both official GDP and the alternatives have explanatory power over the various dependent variables. By contrast, during the more recent periods, official GDP has little explanatory power over China's imports and the other macro 
Chart 9

Industrial Production

Value added of industry

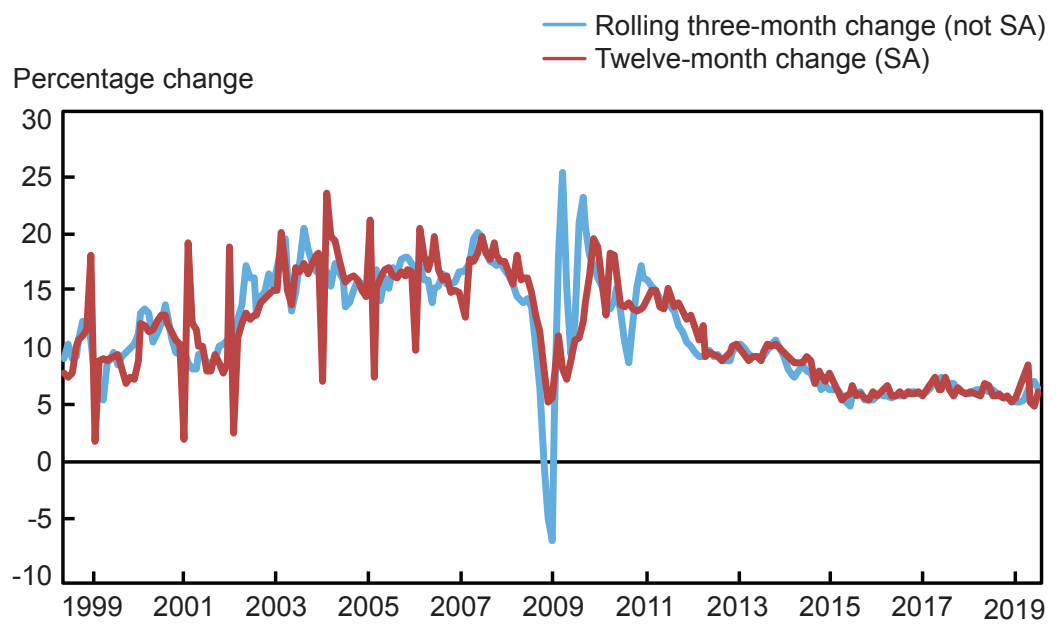

Source: National Bureau of Statistics of China via CEIC Data.

Note: The chart plots industrial production data as a twelve-month percentage change (not seasonally adjusted (SA)) and as a rolling three-month percentage change (SA at an annual rate).

indicators considered here. The time window that includes the first six months of 2019 shows the re-emergence of explanatory power over China's imports and German manufacturing production, though less so than in the earliest period. That pattern makes sense since from the middle of 2018, China's official GDP has tracked our alternative indicators reasonably closely. By contrast, it is notable how well the alternative indicators retain explanatory power in the two most recent time periods for China's imports, global commodity prices, and industrial production in Japan, Germany, and emerging-market Asia, excluding China and India. This relationship does not hold true for the U.S. data shown in the table; however, as will be discussed below, there are correlations between the U.S. data and certain lags of the alternative indicators.

Chart 6 shows that the output from these alternative models all paints a rather similar picture of China's economic cycles over the long term, though it does deviate at shorter time horizons. For policy formulation, it is often desirable to have a view of economic performance in close to real time, in which case these shorter-term differences can be important. Indeed, the more detailed results shown in Appendix Table 3A suggest that there is a fair amount of heterogeneity among the alternatives. For example, for German manufacturing production in the regressions through mid-2019, the R2s range from a low of 0.06 (NTL-Narrow) to 0.29 (NTL-Broad). Most of the other rows also show a fair amount of variability between R2s and RMSEs as well. This divergence raises the issue of which models truly provide the most accurate picture of Chinese economic activity, and whether the choice of model depends on context.

To explore these issues further, we regressed the dependent variables shown in Table 1 on contemporaneous or lagged (up to six months) alternative indicators. ${ }^{11}$ For this exercise, we 
TABLE 1

China Monthly Growth Indicators (Average Alternative Indicator)

\begin{tabular}{|c|c|c|c|c|c|c|c|c|c|}
\hline \multirow[b]{2}{*}{ Dependent Variable } & \multirow[b]{2}{*}{ Proxy Indicators } & \multicolumn{3}{|c|}{2001 to 2013} & \multicolumn{2}{|c|}{2014 to 2018} & \multicolumn{3}{|c|}{2014 to $2019 \mathrm{~m} 6$} \\
\hline & & $t$-stat & $R^{2}$ & RMSE & $t$-stat & $R^{2}$ & $t$-stat & $R^{2}$ & RMSE \\
\hline \multirow[t]{2}{*}{ China's imports } & Official GDP & 3.96 & 0.56 & 0.66 & 1.32 & 0.33 & 2.65 & 0.34 & 0.81 \\
\hline & Average Alternative & 4.63 & 0.59 & 0.64 & 3.27 & 0.41 & 4.60 & 0.41 & 0.77 \\
\hline \multirow[t]{2}{*}{ Commodity prices } & Official GDP & 5.69 & 0.43 & 0.75 & -0.16 & -0.02 & 0.55 & -0.01 & 1.01 \\
\hline & Average Alternative & 8.37 & 0.50 & 0.71 & 3.37 & 0.43 & 3.96 & 0.44 & 0.75 \\
\hline \multirow[t]{2}{*}{$\begin{array}{l}\text { U.S. manufacturing } \\
\text { industrial production }\end{array}$} & Official GDP & 2.70 & 0.17 & 0.91 & -0.72 & 0.00 & -0.70 & -0.00 & 1.00 \\
\hline & Average Alternative & 2.24 & 0.12 & 0.94 & 0.56 & -0.00 & 0.71 & -0.00 & 1.00 \\
\hline \multirow[t]{2}{*}{ U.S. ISM index } & Official GDP & 2.76 & 0.16 & 0.92 & -0.91 & 0.01 & -0.53 & -0.01 & 1.01 \\
\hline & Average Alternative & 3.94 & 0.28 & 0.85 & 0.73 & 0.00 & 1.08 & 0.01 & 0.99 \\
\hline \multirow[t]{2}{*}{$\begin{array}{l}\text { Germany manufacturing } \\
\text { industrial production }\end{array}$} & Official GDP & 3.78 & 0.26 & 0.86 & 0.85 & 0.01 & 2.54 & 0.17 & 0.91 \\
\hline & Average Alternative & 2.86 & 0.16 & 0.92 & 2.39 & 0.07 & 3.11 & 0.15 & 0.92 \\
\hline \multirow[t]{2}{*}{$\begin{array}{l}\text { Japan industrial } \\
\text { production }\end{array}$} & Official GDP & 3.06 & 0.23 & 0.88 & 0.84 & 0.03 & 1.50 & 0.08 & 0.96 \\
\hline & Average Alternative & 3.39 & 0.24 & 0.87 & 3.73 & 0.35 & 4.28 & 0.37 & 0.79 \\
\hline \multirow{2}{*}{$\begin{array}{l}\text { Emerging-market Asia } \\
\text { industrial production, } \\
\text { excluding China and India }\end{array}$} & Official GDP & 3.10 & 0.24 & 0.87 & -1.09 & -0.00 & 0.85 & -0.00 & 1.00 \\
\hline & Average Alternative & 4.47 & 0.38 & 0.79 & 2.30 & 0.16 & 3.19 & 0.22 & 0.88 \\
\hline
\end{tabular}

Source: Authors' calculations.

Notes: This table shows the results of ordinary-least-squares regressions of the dependent variable, measured independently of China's statistical system, on the Average Alternative proxy indicator. The regression of "China's imports" factors in the real effective exchange rate. All data are monthly and normalized over the regression windows shown. The $t$-values are Newey-West and $R^{2}$ values are adjusted $R^{2}$. RMSE is root-mean-square error. "China's imports" are exports to China and Hong Kong reported by the United States, the European Union, and Japan. Official GDP is as reported by China. The Average Alternative is the arithmetic average of NTL-Narrow, NTL-Broad, and the Average Factor (itself an average of the PCA and SPLS factor-based indicators). 
also separate out the PCA and SPLS indicators. We ran regressions on all the data from the beginning of 2014 through June 2019, and then sorted for each dependent variable the resulting 294 models by their highest R2. The panels in Chart 10 plot the resulting "best fit" alternative indicators against each of the dependent variables. In order to help control for shocks to global demand, we conducted a similar exercise in which we calculated a partial R2 from regressions of the same dependent variables on the Chinese alternative indicators, holding constant the impacts of a global demand factor. ${ }^{12}$ We also sorted these results by the highest partial R2 for each dependent variable. Table 2 summarizes these results, showing just the top-ranked model for each dependent variable. Appendix Table 3B shows the same for the top five ranked models for each dependent variable.

The results warrant several observations. First, the simple regressions do show explanatory power between the alternatives and the U.S. variables once one accounts for a lagged relationship, though this relationship disappears after we control for global demand. Second, it is notable how well the simple PCA indicator performs, showing up with the highest explanatory power in four of the seven dependent variables, and completely dominating the rankings in the models for U.S. manufacturing. However, once we try to control for global demand, the PCA model performs less well and is dominated by the other models, most frequently the broader models (SPLS, NTL-Broad); the NTL-Narrow ranks at the top of the regressions involving Japanese industrial production but generally does not place in the top five.

These results raise questions about the use of models such as the simple PCA as a proxy for Chinese growth. The broad PCA used here-covering sixty-two Chinese data series-clearly is correlated with Chinese activity and enjoys the advantage of being easy to compute in a policy setting. But, at the same time, it is perhaps overly influenced by industrial activity and China's central role in global value chains and, hence, economic activity outside of China. This result supports the use of the more targeted approaches taken in the SPLS and NTL indicators, which tailor the indicators to data that more directly measure Chinese growth. Another approach is the methodology of Fernald, Hsu, and Spiegel (2019; 2015), which addresses the problem by tailoring variables for a principal component based on their explanatory power over Chinese imports.

Our results also caution against overreliance on narrow indicators such as the popular Li Keqiang index, which forms the core of the NTL-Narrow indicator. As discussed in Section 2, the Li Keqiang variables-loans, rail freight, and electricity-consistently show statistically significant coefficients in satellite nighttime lights regressions for economic growth, virtually the only variables that do so, incorporating data over the period 2004 to 2013. This performance supports the use of these variables, with appropriate weighting, as Chinese growth proxies. However, the relationships between these indicators and growth likely are not stable given China's rapid pace of structural change, including in the financial sector. Moreover, a narrow set of indicators may not adequately proxy for China's consumer sector, which has been growing rapidly. Against this backdrop, the broader models considered here-SPLS and NTL-Broad-appear to have the edge in terms of their correlations with other indicators of Chinese growth.

Nonetheless, the "best" model of Chinese activity is likely to vary over time and circumstance. For example, data on labor markets, household and government consumption, the retail sector, and services in China are quite sparse, of questionable quality, or in some cases possibly "politically smoothed" (Goldman Sachs 2017). Models that use retail sales as a proxy for consumption-as do the SPLS and NTL-Broad-may understate a growth slowdown if 
Chart 10

Global Variables and the Best-Fit Alternative Indicators

- China's imports

- LO (NTL-Broad)

Percent

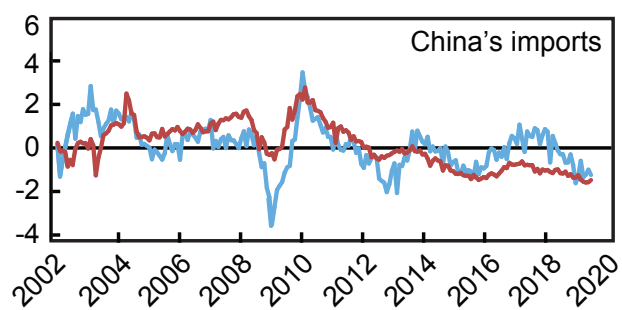

- Commodity prices

- L0 (PCA)

Percent

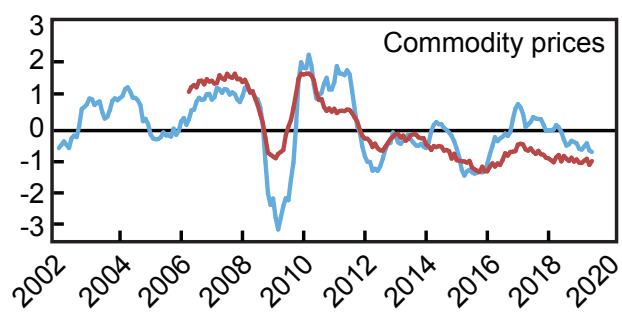

- U.S. manufacturing industrial production Percent - L3 (PCA)

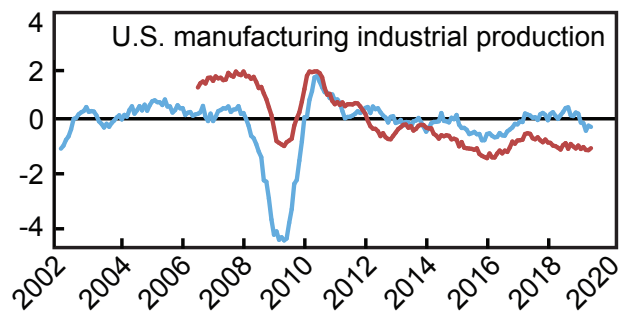

- Germany manufacturing production — LO (NTL-Broad)

Percent

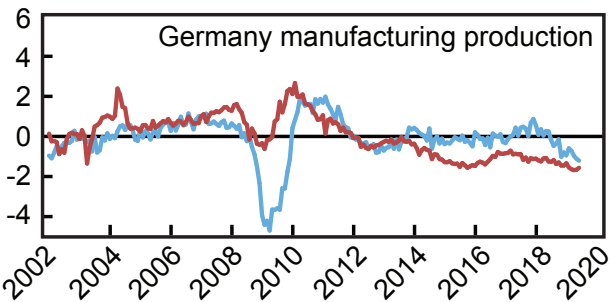

- Japan industrial production — LO (NTL-Broad)

Percent

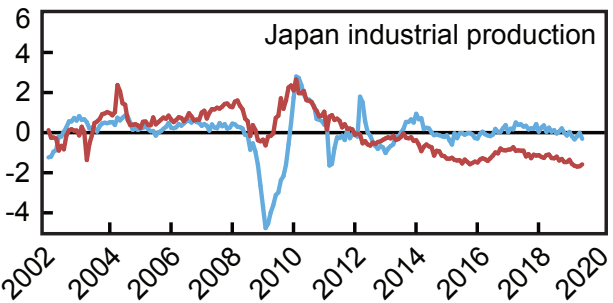

- EM Asia excluding China and India - LO (PCA)

Percent

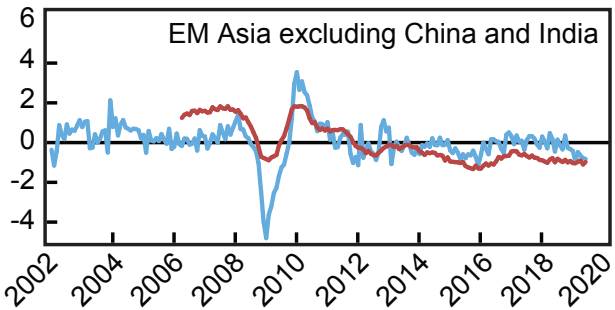

- U.S. ISM index

- L3 (PCA)

Percent

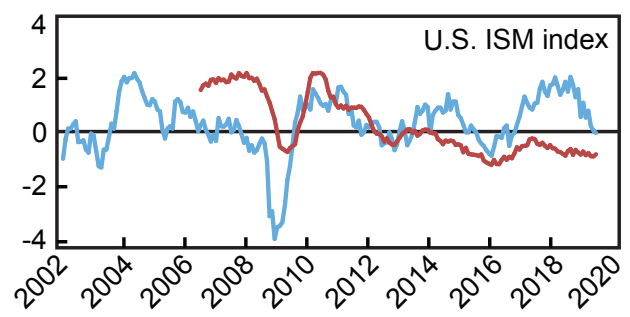

Source: Authors' calculations.

Notes: EM is emerging market. LO indicates that the regressors are contemporaneous and L3 denotes a lag of three months. 
TABLE 2

The Best-Fit Models among All Regressions

Based on the highest $R^{2}$ or partial $R^{2}$

\begin{tabular}{|c|c|c|}
\hline Dependent Variable & Simple Regression & Global Demand Partialed Out \\
\hline China's imports & L0.(NTL-Broad) & L0.(NTL-Broad) \\
\hline Commodity prices & L0.(PCA) & L0.(PCA) \\
\hline $\begin{array}{l}\text { U.S. manufacturing industrial } \\
\text { production }\end{array}$ & L3.(PCA) & L0.(SPLS) \\
\hline U.S. ISM index & L3.(PCA) & L0.(NTL-Narrow) \\
\hline $\begin{array}{l}\text { Germany manufacturing industrial } \\
\text { production }\end{array}$ & L0.(NTL-Broad) & L0.(NTL-Broad) \\
\hline Japan industrial production & L1.(NTL-Broad) & L1.(NTL-Narrow) \\
\hline $\begin{array}{l}\text { Emerging-market Asia industrial } \\
\text { production, excluding China } \\
\text { and India }\end{array}$ & L0.(PCA) & L0.(PCA) \\
\hline
\end{tabular}

Source: Authors' calculations.

Notes: This results are based on iterative regressions of the dependent variable on the alternative growth indicators for China: NTL-Narrow, NTL-Broad, principal components analysis (PCA), sparse partial least squares (SPLS), the Average Alternative (an average of the prior four models), and the Average Factor (an average of the PCA and SPLS factor-based models). The regressors were either contemporaneous (LO) or lagged from 1 to 6 months (L1 ... L6). ISM is Institute for Supply Management. See Appendix Table 3B for full details.

consumption weakens by more than captured in official statistics. However, models that are heavily influenced by developments in the industrial sector may overstate a slowdown if household consumption is otherwise relatively stable. Policy analysts and market participants typically have a point of view on these developments based on experience and close following of the Chinese economy, news stories, social media, and other such indicators. For these reasons, we would caution against reliance on a single alternative indicator.

\section{What about the Longer Cycle?}

In this article, we have focused on the Chinese business cycle as opposed to its longer-term trend growth. In fact, the methodologies employed by the PCA and SPLS are calculated from detrended data, after which the trend from official GDP is reintroduced to make the models' output comparable to the NTL indicators as well as to official GDP. As a result, the factor-based 
indicators discussed in this article do not provide information on trend GDP independent of the official figures themselves. Nonetheless, parsing trend from cycle is important from many perspectives. For example, there is a risk of conflating a general trend-growth slowdown in China with a "hard landing." In the period after the global financial crisis, concerns over hard landings in China have periodically contributed to global market volatility and tightening of financial conditions.

On the trend side, a key observation is that China's growth is clearly slowing. In fact, the alternative indicators and China's own official GDP are consistent on this point. In a related article in this special issue, Higgins (2020) sketches out three scenarios for China's growth over the next twenty years, referred to as Humdrum, Pretty Good, and Golden. The Humdrum scenario shows real per capita income growth slowing to an average 2.7 percent in the first decade and 0.9 percent in the second. The equivalent growth rates for the Pretty Good scenario are a respective 3.8 percent and 2.1 percent in the first and second decades; for the Golden scenario, they are 4.9 percent and 2.6 percent, respectively. Without taking a stand on which scenario will come to pass, Higgins notes that all three scenarios put real per capita income growth well below the rate of about 6 percent in 2018 (based on the official growth rate). Thus, it appears likely that cycles in China's "true" growth will fluctuate around a substantially declining trend.

On the cycles themselves, the first observation to make is to stress the key point of this article: that China's economy has shown clear cyclical variation and there is no evidence that these cycles have largely disappeared, as portrayed in the official data. These cycles can have a large influence over the global economy as China's economy has grown to become a major powerhouse.

The alternative indicators suggest that there have been five complete business cycles in the post-WTO period, and that China entered a new cycle beginning in the second quarter of 2017, the end of which had not yet been apparent through mid-2019. The troughs of these cycles occurred in the fourth quarter of 2001, the fourth quarter of 2004, the fourth quarter of 2008, the third quarter of 2012, and the fourth quarter of 2015. As illustrated in Chart 11, the data indicate that the frequency of these cycles (as measured peak to peak or trough to trough) has been fairly steady at about fourteen quarters. However, upturns in growth have been much shorter in duration in the last three cycles than in the first two, while slowdowns have lasted much longer. In the last three cycles, upturns (trough to peak) have lasted, on average, only a bit more than four quarters, compared with ten to twelve quarters in the early cycles. Downturns lasted a year or less in the first two cycles but for over two years in the more recent three slowdowns.

The timing of these cycles is certainly influenced by global factors outside of China's control, but nonetheless is heavily determined by domestic policy choices as well. China's leadership has been grappling with fallout from years of overinvestment in heavy industry and real estate, and build-ups of debt in the corporate, government, and household sectors. As a result, the authorities have been trying to manage financial stability risks and economic growth goals by alternately tightening and loosening credit and fiscal policies. Given growing concerns over financial stability risks, in the period after the global financial crisis the authorities evidently have been more willing to tolerate longer periods of slowing economic growth than they were in the past. At the same time, though, concerns over social stability make the authorities resistant to allowing slowdowns to last too long or become too deep, prompting the eventual reversions to stimulus that is evident in the data. 
CHART 11

China's Post-WTO Business Cycles

As measured by the Average Alternative

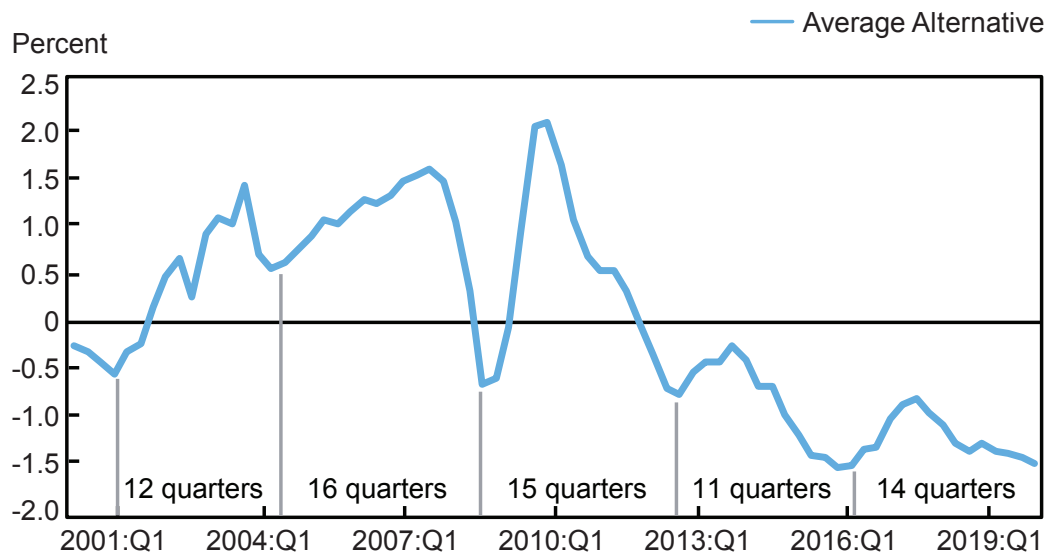

Source: Authors' calculations.

Notes: WTO is World Trade Organization. Data are normalized with a mean equal to zero and a standard deviation of 1 .

Against this backdrop, it is reasonable to expect continued growth fluctuations around a substantially slowing trend. China's policymakers historically have had ample tools to boost growth quickly whenever needed, but these tools may become weaker over time. The most powerful policy tools are oriented around investment and credit, but as noted by

Higgins (2020), contributions to growth from capital accumulation ultimately are self-limiting, since ever-greater shares of new investment outlays are needed to simply keep the capital stock from shrinking. In this context, China's credit impulse will have less "bang for the yuan" as time passes; indeed, China is already witnessing substantial declines in contributions to growth from capital accumulation. Of course, China's government could choose to "double down" on its investment-intensive growth model and increase the share of capital expenditure in GDP, but such a strategy would lead to a build-up in financial stability risks-an acute concern for authorities.

\section{Conclusion}

In this article, we have argued that China's official data on GDP growth appear implausibly smooth in recent years. This steadiness calls into question the usefulness of China's official growth data in forecasting and in making policy and business decisions, at least in recent years. Accordingly, we have constructed a set of alternative growth proxies, the methodologies of which revolve around satellite nighttime lights, principal component analysis, and sparse partial least squares regression. These proxies are more volatile than China's official data, show 
changes that are plausible with respect to domestic economic data and policy developments, and retain considerable explanatory power over other global economic variables that China should influence. In terms of magnitude, growth slowdowns during 2014-15 and 2017-19 were about twice as large in percentage points of growth as those officially reported, while a growth rebound in 2016 seen in the alternative indicators was scarcely reported in official statistics. The growth slowdown during 2017 through mid-2019 was not as deep as the 2014-15 slowdown-measuring somewhat more than half the size of the slowdown as the previous period. Official GDP data have tracked the alternative indicators relatively closely from the third quarter of 2018 through the second quarter of 2019.

While our analysis indicates that cyclical movements in China's economy have remained quite pronounced over the past half-decade, it does not necessarily imply that the growth rates themselves are much lower than officially reported. Indeed, Clark, Pinkovskiy, and Sala-i-Martin (2020) found little basis for such an assertion. Nonetheless, it is already evident, both from the alternative indicators and from official GDP, that average growth rates have slowed substantially, and the outlook over the next few decades is for trend growth to slow by significantly more. At the same time, policymakers will have less room for stimulus as the efficacy of capital accumulation fades. Eventually, trend growth may be low enough that "growth recessions" may materialize into actual contractions-an outcome not yet evident in our alternative indicators.

The fluctuations in growth suggested by the alternative indicators are large enough to have economically significant impacts on global commodity markets and emerging-market economies. As discussed in Akinci, Benigno, and Pesenti (2020), a slowdown similar to that in 2017-18 should have fairly moderate impacts on the U.S. economy through normal trade channels. However, the impact of any slowdown in the Chinese economy would become larger as the country's financial system becomes more integrated into global markets or if such a slowdown triggered adverse shocks to financial markets and business confidence. Moreover, a higher-magnitude Chinese slowdown, such as occurred during 2014-15, could have a meaningful impact even through normal trade channels alone. 


\section{Appendix 1: Additional Detail on Nighttime Lights Methodology}

In this appendix we summarize the methodology described in detail in Clark, Pinkovskiy, and Sala-i-Martin $(2017 ; 2020)$, and discuss a few additional details of how this methodology was operationalized at a monthly frequency in this article to support real-time policy work.

The nighttime lights satellite data are collected by the Defense Meteorological Satellite Program Operational Linescan System (DMSP-OLS). These data are maintained and processed by the National Oceanic and Atmospheric Administration's National Centers for Environmental Information (formerly National Geophysical Data Center). Satellites orbit the Earth, sending images of every location between 65 degrees south latitude and 65 degrees north from 8:30 p.m. to 10 p.m. local time. The images are processed to remove cloud cover, snow, and ephemeral lights (such as forest fires). They are then averaged over time for stability and to limit seasonality. The final product is publicly available for download at an annual frequency for years between 1992 and 2013. ${ }^{13}$

Each pixel (1 square kilometer) in the luminosity data is assigned a digital number (DN) representing its luminosity. The DNs are integers that range from 0 to 63 . We construct our lights proxy for aggregate income by summing up all the digital numbers across the pixels. This method has been widely used in the literature on nighttime lights in economics, including Henderson, Storeygard, and Weil (2012) and Michalopoulos and Papaioannou (2013; 2014). For years with multiple satellites available, we average the logarithms of our aggregate luminosity measure, following Henderson, Storeygard, and Weil (2012).

Although it is well-established that lights are strongly correlated with measures of economic activity, such as national accounts GDP, in levels and growth rates, there are also well-known problems with the relationship between nighttime lights and economic development that need to be taken into account. When the data from the DMSP-OLS satellites are used, pixels with $\mathrm{DN}$ equal to 0 or 63 are top- or bottom-censored. For example, the lights data are also affected by overglow and blooming, meaning that light tends to travel to pixels outside of those in which it originates, and that light tends to be magnified over certain terrain types such as water and snow cover (Doll, Muller, and Morley 2006). Given that this research is based on national-level estimates of aggregate lights, it is unlikely that these sources of error will be large enough or sufficiently correlated with important variables to confound our analysis. Another problem may be that satellites age in space and are eventually retired. Hence, they might give inconsistent readings from year to year, or new satellites may give fundamentally different readings from old ones. While some evidence of this problem exists, the mathematical framework in the next section suggests that our calculations are supported by assumptions that allow nighttime lights to have all of the data problems described above, so long as nighttime lights are correlated with true income. We also address this problem by including year fixed effects (sometimes additionally interacted with cross-sectional variation) in all specifications.

We now turn to summarizing the mathematical framework for our methodology, which was developed in Pinkovskiy and Sala-i-Martin (2016a; 2016b). 


\section{APPENDIX 1 (Continued)}

Let $y_{i, t}^{*}$ be the unobserved, true value of GDP in location $i$ in time period $t, y_{i, t}^{A}$ and $y_{i, t}^{B}$ be observed proxies of economic activity, and $y_{i, t}^{L}$ be the amount of nighttime light.

We can always write:

$$
\begin{gathered}
y_{i, t}^{L}=f_{i, t}\left(y_{i, t}^{*}\right)+\varepsilon_{i, t}^{L} \\
y_{i, t}^{A}=\alpha_{A}+\beta_{A} y_{i, t}^{*}+\varepsilon_{i, t}^{A} \\
y_{i, t}^{B}=\alpha_{B}+\beta_{B} y_{i, t}^{*}+\varepsilon_{i, t}^{B}
\end{gathered}
$$

where $f_{i, t}\left(y_{i, t}^{*}\right)$ may be some nonlinear function of the unobserved true GDP $y_{i, t}^{*}$, and the epsilons are measurement errors. To discipline this structure, we make the following assumptions:

$$
\text { A0) } \operatorname{cov}\left(y_{i, t}^{*}, f_{i, t}\left(y_{i, t}^{*}\right)\right) \neq 0 \text {, }
$$

(lights are correlated with true income)

$$
\text { A1) } E\left(\varepsilon_{i, t}^{L} \mid y_{i, t}^{*}\right)=E\left(\varepsilon_{i, t}^{A} \mid y_{i, t}^{*}\right)=E\left(\varepsilon_{i, t}^{B} \mid y_{i, t}^{*}\right)
$$

(measurement errors are uncorrelated with true income)

$$
\text { A2) } E\left(\varepsilon_{i, t}^{A} \varepsilon_{i, t}^{L} \mid y_{i, t}^{*}\right)=E\left(\varepsilon_{i, t}^{B} \varepsilon_{i, t}^{L} \mid y_{i, t}^{*}\right)=0
$$

(measurement error in lights is uncorrelated with other measurement errors).

Under assumptions A0-A2, Clark, Pinkovskiy, and Sala-i-Martin (2020) show that running the regression

$$
y_{i, t}^{L}=\alpha+b_{A} y_{i, t}^{A}+b_{B} y_{i, t}^{B}
$$

will yield coefficients $b_{A}$ and $b_{B}$ that are proportional to the weights on $y_{i, t}^{A}$ and $y_{i, t}^{B}$ in the best unbiased linear predictor of $y_{i, t}^{*}$ based on the proxies $y_{i, t}^{A}$ and $y_{i, t}^{B}$.

Clark, Pinkovskiy, and Sala-i-Martin (2020) found that running regressions on the 2005-13 sample of Chinese provinces with the Li Keqiang variables and log real GDP as the candidate proxy measures gave an optimal weight of about 60 percent on loan growth, 30 percent on electricity growth, and 10 percent on railroad freight growth. Running this regression on a broader subset of variables used by Fernald, Hsu, and Spiegel (2015) generated no new additional variables with statistically significant weights, with the exception of retail sales if price deflators were included in the regressions. We concluded that an optimal estimator of Chinese economic performance should put considerable weight on loan growth.

One challenge of comparing the resulting best unbiased linear predictor of Chinese growth to the official GDP series is that our methodology does not identify the location or scale of GDP. Clark, Pinkovskiy, and Sala-i-Martin (2020) addressed this problem by calculating the 


\section{Appendix 1 (Continued)}

fitted values of the regression of official national quarterly GDP growth rates on the optimally weighted national quarterly candidate proxy growth rates as our best unbiased linear predictor. The fit of this regression is quite good. However, even without relying on the assumption that official GDP is a good measure of "true" growth, we can compare the values of our best unbiased linear predictor in one time period to the values in another time period. Therefore, we can make statements such as "Chinese growth in the fourth quarter of 2018 was higher than Chinese growth in the fourth quarter of 2015," or that "the decline in Chinese growth over 2018 has been smaller than the decline in Chinese growth during 2015," without relying on any scaling assumptions.

Another important challenge for using these indicators for current policy work is that financial conditions are likely not as well captured by loans as they were over our in-sample period. For reasons of data availability, we had to use data on loans in the provincial regressions. However, within the past decade the broader concept of "aggregate financing" - of which "shadow credit" is an important component-has taken on greater importance in China's credit cycle. The use of loans in our NTL growth indexes would therefore likely misrepresent financial conditions in China during both the 2014-15 and the most recent cycles. This is because the authorities have alternately tightened and loosened credit in the so-called "shadow finance" sector, leading to substantial fluctuations in aggregate financing, and hence tightening and loosening of credit conditions. By contrast, bank loan growth has been much more stable as the authorities have taken measures to move off-balance-sheet financial activities back onto bank balance sheets.

As a workaround for this problem, the NTL-based alternative indicators in this article use M2 instead of loans in the calculation of the indexes used to make in and out-of-sample estimates of GDP growth. The reason for this substitution is that we can be a bit more conservative in how we capture credit conditions. We believe that changes in M2 growth serve as a useful "middle ground" between aggregate financing and loans in representing true credit conditions in our period of interest. Appendix Charts $1 \mathrm{~A}$ and $1 \mathrm{~B}$ show the twelve-month growth rates of M2, loans, and aggregate financing and their rolling correlations. For most of China's history-including the period in our estimation sample-money, loans, and aggregate financing have been quite strongly correlated, with correlations usually ranging from 0.8 to 0.95 . However, in more recent years, the relationship between M2 and loans has weakened, while the one between M2 and aggregate financing has remained higher. In the most recent cycle, from the first quarter of 2017 to the second quarter of 2019, M2 growth has fallen by about half as much as aggregate financing, while loan growth was little changed overall. We argue that true credit availability for the "real economy" was likely not as steady as implied by loan growth, nor as tight as implied by aggregate financing, and hence is better represented by M2 growth. 


\section{Appendix 1 (Continued)}

Chart 1A

M2 Growth Serves as a Middle Ground for Gauging Credit Conditions

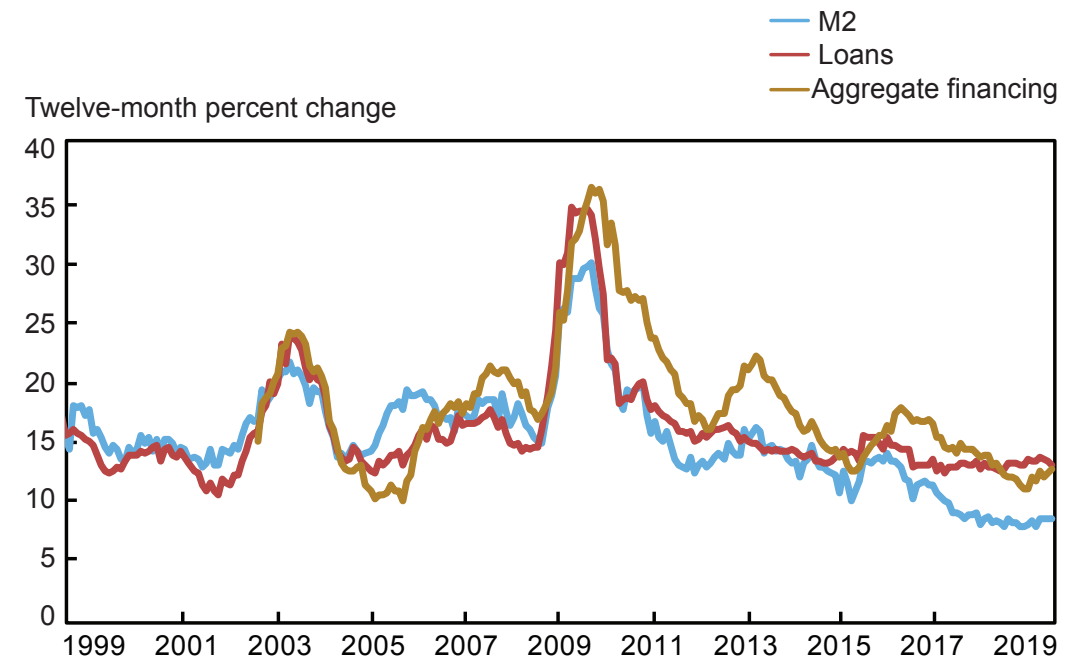

Sources: People's Bank of China via CEIC Data; authors' calculations.

CHART 1B

Relationships between Credit Condition Measures Have Weakened Somewhat

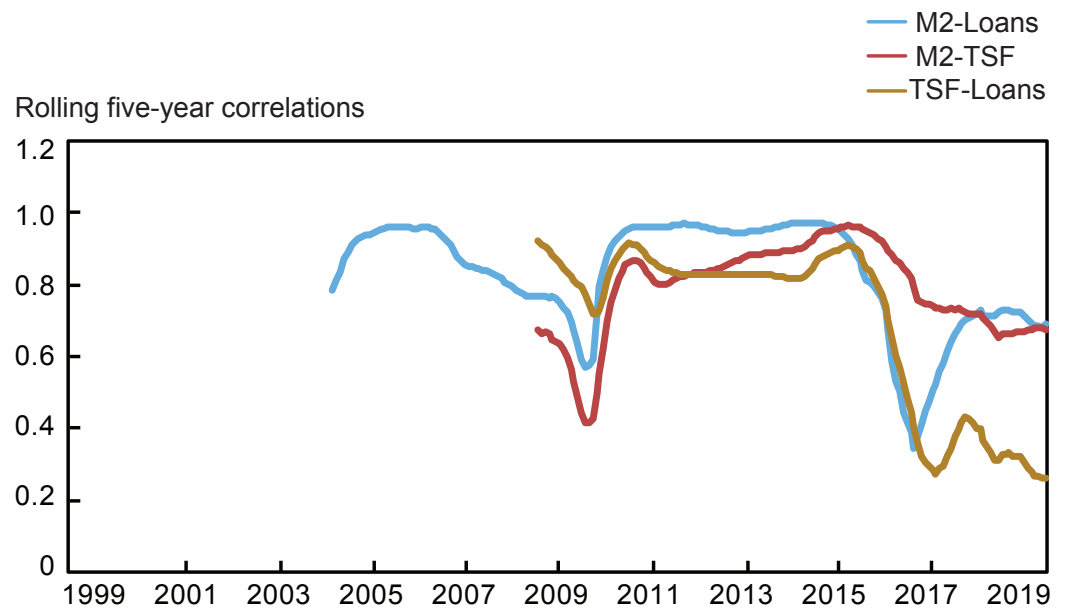

Sources: People's Bank of China via CEIC Data; authors' calculations. 


\section{Appendix 2: Notes on the Data}

\section{General Observations}

The data used in this article come from official sources (National Bureau of Statistics of China and People's Bank of China) and are accessed via the CEIC Data's Premium China Database. The underlying frequency of the data used here is monthly, except for GDP and the fixed asset investment (FAI) price deflator, which are quarterly and converted to monthly frequency via linear interpolation. Data published in year-to-date format are converted to monthly frequency by subtracting the current from the previous observation. All twelve-month changes are computed from seasonally adjusted data, for which measures are taken to control for the timing of the Chinese New Year. Certain series are problematic in that the availability of data for January and/or February varies over the history of the series (for example, data for January and February are published in some years, some years exclude January, and some years exclude both). For these series, we discard January and February from the entire series, linearly interpolate the gaps, and seasonally adjust the modified data. ${ }^{14}$ With the exceptions of value-added by private industry (VAI) and the purchasing manager's index (PMI), all data are seasonally adjusted by the authors using the TRAMO-SEATS algorithm within the U.S. Census Bureau's X13-ARIMA program. The VAI and PMI data are seasonally adjusted by the authorities.

\section{Specific Notes}

Credit: Data problems make it difficult to construct consistent time series for credit. China most recently revised its aggregate credit series in July 2018 and again in September 2018; revisions for the outstanding levels of aggregate credit were not carried back further than 2016, and the stocks implied from the flows, in general, have not been internally consistent. As a simple workaround, we construct credit levels derived from reported flows, for which there is a more consistent historical series. We also make additional adjustments for the inclusion of certain local government bond issuance and the exclusion of equity financing and loan write-offs.

Fixed asset investment (FAI): China's FAI data suffer from many well-known statistical shortcomings (Orlik 2012). The major problems include coverage of investment expenditure on both new and existing machinery and structures; purchases of land; publication only in year-to-date nominal terms; inclusion of expenditure on not-yet completed investments; and periodic, highly nontransparent data revisions. Data revisions were particularly problematic during 2017-18, when large discrepancies developed between officially published twelve-month percentage changes and directly calculated changes from the published levels, with the former reportedly "adjusted" by the authorities to make them comparable to previous data. In this article, we calculate index levels from the official twelve-month percentage changes. Specifically, we identify years during which there is little or no discrepancy between twelve-month percentage changes, and using those official levels, we extrapolate forward and backward using the official data on percentage change. These calculated index levels are then fed into our seasonal adjustment and subsequent modeling procedures. 


\section{Appendix 2 (Continued)}

Summary of Data Employed for Each Growth Proxy Indicator

\begin{tabular}{|c|c|c|c|c|c|c|}
\hline & \multicolumn{3}{|c|}{ Sparse Factor } & \multirow[b]{2}{*}{$\begin{array}{l}\text { Simple } \\
\text { Factor }\end{array}$} & \multirow[b]{2}{*}{$\begin{array}{l}\text { NTL- } \\
\text { Narrow }\end{array}$} & \multirow[b]{2}{*}{$\begin{array}{l}\text { NTL - } \\
\text { Broad }\end{array}$} \\
\hline & V1 & $\mathrm{V} 2$ & $\mathrm{~V} 3$ & & & \\
\hline Consumer confidence index & & & $\mathrm{x}$ & $\mathrm{x}$ & & \\
\hline Consumer expectation index & $\mathrm{x}$ & & & $\mathrm{x}$ & & \\
\hline Value added of industry & $\mathrm{x}$ & $\mathrm{x}$ & $\mathrm{x}$ & $\mathrm{x}$ & & \\
\hline Electricity production & $\mathrm{x}$ & $\mathrm{x}$ & $\mathrm{x}$ & $\mathrm{x}$ & $\mathrm{x}$ & $\mathrm{x}$ \\
\hline Iron ore production & $\mathrm{x}$ & & $\mathrm{x}$ & $\mathrm{x}$ & & \\
\hline Pig iron production & $\mathrm{x}$ & & & $\mathrm{x}$ & & \\
\hline Crude steel production & $\mathrm{x}$ & & & $\mathrm{x}$ & & \\
\hline Steel product production & $\mathrm{x}$ & & & $\mathrm{x}$ & & \\
\hline Apparent crude demand & & & & $\mathrm{x}$ & & \\
\hline Apparent refined demand & $\mathrm{x}$ & & & $\mathrm{x}$ & & \\
\hline Copper production & $\mathrm{x}$ & & & $\mathrm{x}$ & & \\
\hline Aluminum production & $\mathrm{x}$ & & $\mathrm{x}$ & $\mathrm{x}$ & & \\
\hline Cement production & $\mathrm{x}$ & & $\mathrm{x}$ & $\mathrm{x}$ & & \\
\hline Plate glass production & $\mathrm{x}$ & & & $\mathrm{x}$ & & \\
\hline $\begin{array}{l}\text { Real estate investment } \\
\text { production }\end{array}$ & $\mathrm{x}$ & & $\mathrm{x}$ & $\mathrm{x}$ & & \\
\hline Floor space started & $\mathrm{x}$ & & & $\mathrm{x}$ & & $\mathrm{x}$ \\
\hline $\begin{array}{l}\text { Floor space under } \\
\text { construction (Residential) }\end{array}$ & $\mathrm{x}$ & & $\mathrm{x}$ & $\mathrm{x}$ & & \\
\hline Floor space completed & $\mathrm{x}$ & & & $\mathrm{x}$ & & \\
\hline
\end{tabular}




\section{Appendix 2 (Continued)}

\begin{tabular}{|c|c|c|c|c|c|c|}
\hline & \multicolumn{3}{|c|}{ Sparse Factor } & \multirow[b]{2}{*}{$\begin{array}{l}\text { Simple } \\
\text { Factor }\end{array}$} & \multirow[b]{2}{*}{$\begin{array}{l}\text { NTL- } \\
\text { Narrow }\end{array}$} & \multirow[b]{2}{*}{$\begin{array}{l}\text { NTL- } \\
\text { Broad }\end{array}$} \\
\hline & V1 & V2 & V3 & & & \\
\hline Floor space sold & & & & $\mathrm{x}$ & & \\
\hline Imports of iron ore (Volume) & & & $\mathrm{x}$ & $\mathrm{x}$ & & \\
\hline $\begin{array}{l}\text { Steel product imports } \\
\text { (Volume) }\end{array}$ & $\mathrm{x}$ & & & $\mathrm{x}$ & & \\
\hline Imports of unwrought copper & $\mathrm{x}$ & & $\mathrm{x}$ & $\mathrm{x}$ & & \\
\hline Imports of copper waste & $\mathrm{x}$ & & $\mathrm{x}$ & $\mathrm{x}$ & & \\
\hline $\begin{array}{l}\text { Imports of unwrought } \\
\text { aluminum }\end{array}$ & $\mathrm{x}$ & & $\mathrm{x}$ & $\mathrm{x}$ & & \\
\hline Steel products exports & $\mathrm{x}$ & & $\mathrm{x}$ & $\mathrm{x}$ & & \\
\hline $\begin{array}{l}\text { Unwrought copper } \\
\text { export volume }\end{array}$ & & & & $\mathrm{x}$ & & \\
\hline $\begin{array}{l}\text { Unwrought aluminum } \\
\text { export volume }\end{array}$ & $\mathrm{x}$ & & & $\mathrm{x}$ & & \\
\hline Nominal retail sales & & & & $\mathrm{x}$ & & $\mathrm{x}$ \\
\hline Real retail sales & & & & $\mathrm{x}$ & & \\
\hline $\begin{array}{l}\text { Nominal fixed-asset } \\
\text { investment }\end{array}$ & & & & $\mathrm{x}$ & & \\
\hline Real fixed-asset investment & & & & $\mathrm{x}$ & & \\
\hline Real estate investment & & & & $\mathrm{x}$ & & $\mathrm{x}$ \\
\hline Auto sales & $\mathrm{x}$ & $\mathrm{x}$ & $\mathrm{x}$ & $\mathrm{x}$ & & \\
\hline Rail freight & & & & $\mathrm{x}$ & $\mathrm{x}$ & $\mathrm{x}$ \\
\hline Air pass-through & $\mathrm{x}$ & & & $\mathrm{x}$ & & $\mathrm{x}$ \\
\hline Total pass-through & & & & $\mathrm{x}$ & & \\
\hline Petrol imports & $\mathrm{x}$ & & $\mathrm{x}$ & $\mathrm{x}$ & & \\
\hline Foreign reserves & & & $\mathrm{x}$ & $\mathrm{x}$ & & \\
\hline Exchange rate (USD) & $\mathrm{x}$ & & & $\mathrm{x}$ & & \\
\hline
\end{tabular}




\section{Appendix 2 (Continued)}

\begin{tabular}{|c|c|c|c|c|c|c|}
\hline & & se Fa & & & & \\
\hline & V1 & V2 & V3 & $\begin{array}{l}\text { Simple } \\
\text { Factor }\end{array}$ & $\begin{array}{l}\text { NTL- } \\
\text { Narrow }\end{array}$ & $\begin{array}{l}\text { NTL- } \\
\text { Broad }\end{array}$ \\
\hline $\begin{array}{l}\text { Shanghai Stock } \\
\text { Exchange index }\end{array}$ & & & $\mathrm{x}$ & $\mathrm{x}$ & & \\
\hline $\begin{array}{l}\text { Shenzhen Stock } \\
\text { Exchange index }\end{array}$ & & & $\mathrm{x}$ & $\mathrm{x}$ & & \\
\hline $\begin{array}{l}\text { PE ratio for Shanghai } \\
\text { Stock Exchange }\end{array}$ & $\mathrm{x}$ & & $\mathrm{x}$ & $\mathrm{x}$ & & \\
\hline $\begin{array}{l}\text { PE ratio for Shenzhen } \\
\text { Stock Exchange }\end{array}$ & & & $\mathrm{x}$ & $\mathrm{x}$ & & \\
\hline Producer price index & $\mathrm{x}$ & $\mathrm{x}$ & $\mathrm{x}$ & $\mathrm{x}$ & $\mathrm{x}$ & \\
\hline Consumer price index & $\mathrm{x}$ & & $\mathrm{x}$ & & & \\
\hline M1 & $\mathrm{x}$ & & $\mathrm{x}$ & $\mathrm{x}$ & & \\
\hline M2 & & & & $\mathrm{x}$ & & \\
\hline Official PMI & & & & $\mathrm{x}$ & & \\
\hline Export PMI & & & & $\mathrm{x}$ & & \\
\hline Nominal exports & & & & $\mathrm{x}$ & & $\mathrm{x}$ \\
\hline Real exports & & & & $\mathrm{x}$ & & \\
\hline Nominal imports & & & & $\mathrm{x}$ & & \\
\hline Real imports & & & & $\mathrm{x}$ & & \\
\hline Processing exports & & & & $\mathrm{x}$ & & \\
\hline Processing imports & & & & $\mathrm{x}$ & & \\
\hline Non-processing exports & & & & $\mathrm{x}$ & & \\
\hline Non-processing imports & & & & $\mathrm{x}$ & & \\
\hline
\end{tabular}

Table continued on next page 


\section{AppendiX 2 (Continued)}

\begin{tabular}{|c|c|c|c|c|c|c|}
\hline & \multicolumn{3}{|c|}{ Sparse Factor } & \multirow[b]{2}{*}{$\begin{array}{l}\text { Simple } \\
\text { Factor }\end{array}$} & \multirow[b]{2}{*}{$\begin{array}{l}\text { NTL- } \\
\text { Narrow }\end{array}$} & \multirow[b]{2}{*}{$\begin{array}{l}\text { NTL- } \\
\text { Broad }\end{array}$} \\
\hline & V1 & V2 & V3 & & & \\
\hline Trade balance & & & & $\mathrm{x}$ & & \\
\hline $\begin{array}{l}\text { Shanghai-Shenzhen } \\
300 \text { index }\end{array}$ & & & & $\mathrm{x}$ & & \\
\hline Truck sales & & & & $\mathrm{x}$ & & \\
\hline Bank loans & & & & $\mathrm{x}$ & $\mathrm{x}$ & $\mathrm{x}$ \\
\hline Official GDP & & & & & $\mathrm{x}$ & \\
\hline
\end{tabular}

Notes: V1, V2, and V3 refer to the versions of the Sparse Factor Model described in Groen and Nattinger (2020). The nighttime lights (NTL) calibration regressions use bank loan data, which is available at the provincial level. The NTL alternative indexes serving as growth proxies in this article use the coefficients from earlier regressions using loans, but apply them to $\mathrm{M} 2$, to better capture the tightening of financial conditions. See the main text for further explanation. 


\section{Appendix 3: Supplementary Tables}

TABLE $3 \mathrm{~A}$

China Monthly Growth Indicators (Individual Proxy Indicators)

\begin{tabular}{|c|c|c|c|c|c|c|c|c|c|}
\hline \multirow[b]{2}{*}{ Dependent Variable } & \multirow[b]{2}{*}{ Proxy Indicators } & \multicolumn{3}{|c|}{2001 to 2013} & \multicolumn{2}{|c|}{2014 to 2018} & \multicolumn{3}{|c|}{2014 to $2019 \mathrm{~m} 6$} \\
\hline & & $t$-stat & $R^{2}$ & RMSE & $t$-stat & $R^{2}$ & $t$-stat & $R^{2}$ & RMSE \\
\hline \multirow[t]{5}{*}{ China's imports } & Official GDP & 3.96 & 0.56 & 0.66 & 1.32 & 0.33 & 2.65 & 0.34 & 0.81 \\
\hline & Average Alternative & 4.63 & 0.59 & 0.64 & 3.27 & 0.41 & 4.60 & 0.41 & 0.77 \\
\hline & NTL-Narrow & 3.98 & 0.57 & 0.65 & 1.29 & 0.32 & 2.35 & 0.27 & 0.86 \\
\hline & NTL-Broad & 3.61 & 0.56 & 0.66 & 4.49 & 0.48 & 6.24 & 0.51 & 0.70 \\
\hline & Average Factor & 4.66 & 0.58 & 0.64 & 3.32 & 0.43 & 4.49 & 0.41 & 0.77 \\
\hline \multirow[t]{5}{*}{ Commodity prices } & Official GDP & 5.69 & 0.43 & 0.75 & -0.16 & -0.02 & 0.55 & -0.01 & 1.01 \\
\hline & Average Alternative & 8.37 & 0.50 & 0.71 & 3.37 & 0.43 & 3.96 & 0.44 & 0.75 \\
\hline & NTL-Narrow & 5.98 & 0.36 & 0.80 & 2.56 & 0.23 & 3.06 & 0.25 & 0.87 \\
\hline & NTL-Broad & 6.22 & 0.37 & 0.79 & 3.16 & 0.41 & 3.68 & 0.40 & 0.78 \\
\hline & Average Factor & 7.61 & 0.53 & 0.68 & 4.00 & 0.51 & 4.69 & 0.52 & 0.69 \\
\hline \multirow{5}{*}{$\begin{array}{l}\text { Emerging-market Asia } \\
\text { industrial production, } \\
\text { excluding China and India }\end{array}$} & Official GDP & 3.10 & 0.24 & 0.87 & -1.09 & -0.00 & 0.85 & -0.00 & 1.00 \\
\hline & Average Alternative & 4.47 & 0.38 & 0.79 & 2.30 & 0.16 & 3.19 & 0.22 & 0.88 \\
\hline & NTL-Narrow & 4.16 & 0.33 & 0.82 & 1.79 & 0.07 & 2.47 & 0.11 & 0.94 \\
\hline & NTL-Broad & 4.29 & 0.31 & 0.83 & 2.10 & 0.15 & 3.25 & 0.25 & 0.87 \\
\hline & Average Factor & 4.23 & 0.37 & 0.79 & 2.77 & 0.20 & 3.69 & 0.24 & 0.87 \\
\hline \multirow[t]{5}{*}{ Japan industrial production } & Official GDP & 3.06 & 0.23 & 0.88 & 0.84 & 0.03 & 1.50 & 0.08 & 0.96 \\
\hline & Average Alternative & 3.39 & 0.24 & 0.87 & 3.73 & 0.35 & 4.28 & 0.37 & 0.79 \\
\hline & NTL-Narrow & 2.59 & 0.16 & 0.92 & 3.05 & 0.30 & 3.49 & 0.31 & 0.83 \\
\hline & NTL-Broad & 2.83 & 0.16 & 0.92 & 4.20 & 0.36 & 4.96 & 0.40 & 0.77 \\
\hline & Average Factor & 3.64 & 0.29 & 0.84 & 3.46 & 0.30 & 3.83 & 0.32 & 0.83 \\
\hline
\end{tabular}

Table $3 A$ continued on next page 


\section{Appendix 3 (Continued)}

\begin{tabular}{|c|c|c|c|c|c|c|c|c|c|}
\hline \multirow[b]{2}{*}{ Dependent Variable } & \multirow[b]{2}{*}{ Proxy Indicators } & \multicolumn{3}{|c|}{2001 to 2013} & \multicolumn{2}{|c|}{2014 to 2018} & \multicolumn{3}{|c|}{2014 to $2019 \mathrm{~m} 6$} \\
\hline & & $t$-stat & $R^{2}$ & RMSE & $t$-stat & $R^{2}$ & $t$-stat & $R^{2}$ & RMSE \\
\hline \multirow[t]{5}{*}{$\begin{array}{l}\text { Germany manufacturing } \\
\text { industrial production }\end{array}$} & Official GDP & 3.78 & 0.26 & 0.86 & 0.85 & 0.01 & 2.54 & 0.17 & 0.91 \\
\hline & Average Alternative & 2.86 & 0.16 & 0.92 & 2.39 & 0.07 & 3.11 & 0.15 & 0.92 \\
\hline & NTL-Narrow & 1.49 & 0.05 & 0.97 & 1.29 & 0.02 & 2.07 & 0.06 & 0.97 \\
\hline & NTL-Broad & 2.27 & 0.10 & 0.95 & 3.42 & 0.15 & 4.12 & 0.29 & 0.84 \\
\hline & Average Factor & 3.74 & 0.24 & 0.87 & 2.08 & 0.06 & 2.77 & 0.11 & 0.94 \\
\hline \multirow[t]{5}{*}{$\begin{array}{l}\text { U.S. manufacturing } \\
\text { industrial production }\end{array}$} & Official GDP & 2.70 & 0.17 & 0.91 & -0.72 & 0.00 & -0.70 & -0.00 & 1.00 \\
\hline & Average Alternative & 2.24 & 0.12 & 0.94 & 0.56 & -0.00 & 0.71 & -0.00 & 1.00 \\
\hline & NTL-Narrow & 1.38 & 0.05 & 0.97 & -0.32 & -0.01 & -0.26 & -0.01 & 1.01 \\
\hline & NTL-Broad & 1.81 & 0.06 & 0.97 & 0.93 & 0.02 & 1.21 & 0.02 & 0.99 \\
\hline & Average Factor & 2.76 & 0.18 & 0.90 & 0.75 & 0.01 & 0.84 & 0.01 & 1.00 \\
\hline \multirow[t]{5}{*}{ U.S. ISM index } & Official GDP & 2.76 & 0.16 & 0.92 & -0.91 & 0.01 & -0.53 & -0.01 & 1.01 \\
\hline & Average Alternative & 3.94 & 0.28 & 0.85 & 0.73 & 0.00 & 1.08 & 0.01 & 0.99 \\
\hline & NTL-Narrow & 3.56 & 0.21 & 0.89 & -0.23 & -0.02 & -0.03 & -0.02 & 1.01 \\
\hline & NTL-Broad & 4.82 & 0.31 & 0.83 & 1.16 & 0.04 & 1.70 & 0.05 & 0.97 \\
\hline & Average Factor & 3.52 & 0.24 & 0.87 & 0.93 & 0.02 & 1.22 & 0.03 & 0.99 \\
\hline
\end{tabular}

Source: Authors' calculations.

Notes: This table shows the results of ordinary-least-squares regressions of the dependent variable, measured independently of China's statistical system, on the proxy indicators individually. The regression of "China's imports" factors in the real effective exchange rate. All data are monthly and normalized over the regression windows shown. The $t$-values are Newey-West and $R^{2}$ values are adjusted $R^{2}$. RMSE is rootmean-square error. "China's imports" are exports to China and Hong Kong reported by the United States, the European Union, and Japan. Official GDP is as reported by China. The Average Alternative is the arithmetic average of NTL-Narrow, NTL-Broad, and the Average Factor (itself an average of the PCA and SPLS factorbased indicators). 


\section{Appendix 3 (Continued)}

TABLE 3 B

Top Five Alternative Growth Indicators for Each Global Variable

Sorted by $R^{2}$ or partial $R^{2}$

\begin{tabular}{|c|c|c|c|c|c|c|}
\hline & \multicolumn{3}{|c|}{ Simple Bivariate Regressions } & \multicolumn{3}{|c|}{$\begin{array}{l}\text { Regressions with Global Demand } \\
\text { Partialed Out }\end{array}$} \\
\hline & Five Best Models & $t$-stat & $R^{2}$ & Five Best Models & $t$-stat & Partial $R^{2}$ \\
\hline \multirow[t]{5}{*}{ China's imports } & L0.(NTL-Broad) & 6.24 & 0.51 & L0.(NTL-Broad) & 5.63 & 0.32 \\
\hline & L1.(NTL-Broad) & 4.96 & 0.46 & L1.(NTL-Broad) & 4.73 & 0.25 \\
\hline & L6.(SPLS) & 3.95 & 0.45 & L6.(SPLS) & 4.54 & 0.23 \\
\hline & L2.(NTL-Broad) & 4.88 & 0.45 & L3.(SPLS) & 4.47 & 0.23 \\
\hline & L3.(NTL-Broad) & 4.54 & 0.43 & L5.(SPLS) & 4.34 & 0.22 \\
\hline \multirow[t]{5}{*}{ Commodity prices } & L0.(PCA) & 6.58 & 0.59 & L0.(PCA) & 7.51 & 0.46 \\
\hline & L0.(Average Factor) & 4.69 & 0.52 & L0.(Average Factor) & 7.43 & 0.45 \\
\hline & L1.(Average Factor) & 4.03 & 0.46 & L0.(SPLS) & 6.63 & 0.40 \\
\hline & L1.(PCA) & 4.58 & 0.46 & $\begin{array}{l}\text { L0.(Average } \\
\text { Alternative) }\end{array}$ & 6.36 & 0.38 \\
\hline & $\begin{array}{l}\text { L0.(Average } \\
\text { Alternative) }\end{array}$ & 3.96 & 0.44 & L1.(SPLS) & 6.28 & 0.37 \\
\hline \multirow{5}{*}{$\begin{array}{l}\text { U.S. manufacturing } \\
\text { industrial } \\
\text { production }\end{array}$} & L3.(PCA) & 2.83 & 0.26 & L0.(SPLS) & -1.96 & 0.04 \\
\hline & L2.(PCA) & 2.83 & 0.24 & L0.(NTL-Narrow) & -1.80 & 0.03 \\
\hline & L4.(PCA) & 2.64 & 0.23 & L1.(SPLS) & -1.53 & 0.02 \\
\hline & L1.(PCA) & 2.92 & 0.21 & L3.(PCA) & 1.50 & 0.02 \\
\hline & L5.(PCA) & 2.50 & 0.20 & L2.(SPLS) & -1.25 & 0.01 \\
\hline
\end{tabular}

Table 3B continued on next page 


\section{Appendix 3 (Continued)}

Simple Bivariate Regressions

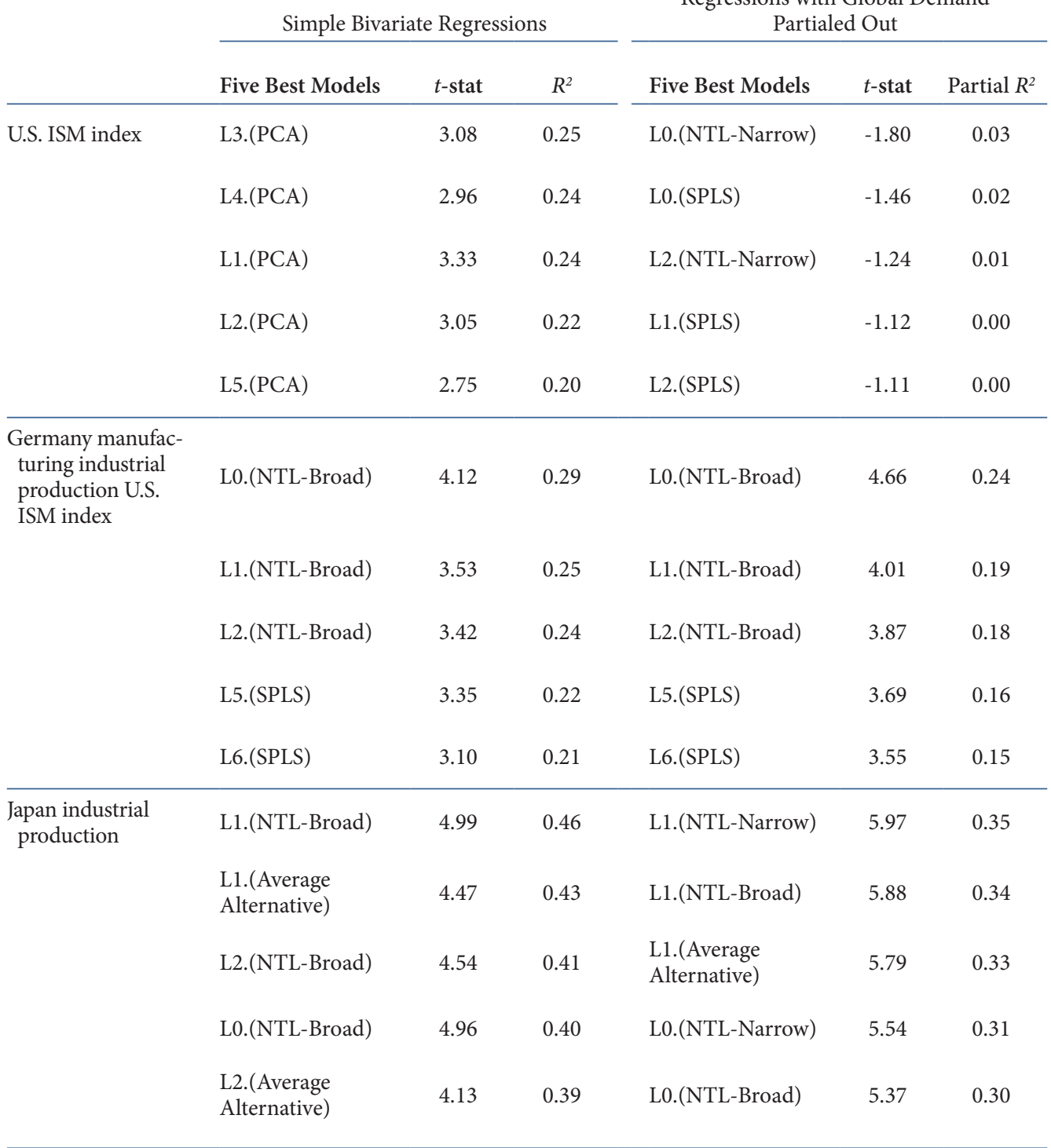

Regressions with Global Demand Partialed Out

Table $3 B$ continued on next page 


\section{Appendix 3 (Continued)}

Simple Bivariate Regressions

Five Best Models
Regressions with Global Demand Partialed Out

\begin{tabular}{|c|c|c|c|c|c|c|}
\hline & Five Best Models & $t$-stat & $R^{2}$ & Five Best Models & $t$-stat & Partial $R^{2}$ \\
\hline \multirow{5}{*}{$\begin{array}{l}\text { Emerging-market } \\
\text { Asia industrial } \\
\text { production, exclud- } \\
\text { ing China and India }\end{array}$} & L0.(PCA) & 4.92 & 0.30 & L0.(PCA) & 4.21 & 0.20 \\
\hline & L0.(NTL-Broad) & 3.25 & 0.25 & L0.(Average Factor) & 3.85 & 0.18 \\
\hline & L0.(Average Factor) & 3.69 & 0.24 & L0.(NTL-Broad) & 3.85 & 0.18 \\
\hline & $\begin{array}{l}\text { L0.(Average } \\
\text { Alternative) }\end{array}$ & 3.19 & 0.22 & $\begin{array}{l}\text { L0.(Average } \\
\text { Alternative) }\end{array}$ & 3.70 & 0.16 \\
\hline & L2.(NTL-Broad) & 2.57 & 0.21 & L0.(SPLS) & 3.34 & 0.14 \\
\hline
\end{tabular}

Source: Authors' calculations.

Notes: The left side of this table presents the results from iterative regressions of the dependent variable on the alternative growth indicators for China: NTL-Narrow, NTL-Broad, principal components analysis (PCA), sparse partial least squares (SPLS), the Average Alternative (an average of the prior four models), and the Average Factor (an average of the PCA and SPLS factor-based models), with the regressors either being contemporaneous (LO) or lagged from 1 to 6 months (L1 ... L6). The right side presents the results of the same set of regressions, but partials out a global demand factor. All regressions involving China's imports include the real effective exchange rate. 


\section{Notes}

${ }^{1}$ See, for example, Rawski (2001), Maddison and Wu (2006), Wu (2014), Holz (2013), Martinez (2018), Hu and Yao (2019), Clark, Pinkovskiy, and Sala-i-Martin (2017; 2020), and references therein.

${ }^{2}$ While we prefer using M2 growth in place of loan growth, both generate very similar predictions for Chinese GDP growth over our in-sample estimation period. In the post-sample period, the level of growth implied by loans is somewhat higher than implied by M2, while the changes in growth are somewhat smaller.

${ }^{3}$ Monthly alternative indicators are calculated using linearly interpolated quarterly GDP growth.

${ }^{4}$ After taking the twelve-month change, the estimation sample begins in April 2006.

5 This SPLS indicator is referred to as model "V3" in Groen and Nattinger (2020).

${ }^{6}$ This characterization holds for the alternative indicators individually as well.

7 The cut to required reserves totaled 100 basis points and had been preannounced in September 2017. It did not result in a reduction in the headline official rate, since as it applied only to selected institutions.

${ }^{8}$ Satellite data in principle could also be a good candidate. However, the high-frequency data are of relatively limited time span and extremely volatile.

${ }^{9}$ Chinese imports follows Fernald, Hsu, and Spiegel (2015) and are defined as exports to China and Hong Kong reported by the United States, Japan, and the European Union. The data are deflated according to the methodology described in the article cited.

${ }^{10}$ This specification follows Fernald, Hsu, and Spiegel (2015). In all the regressions, the real effective exchange rate is statistically significant with the expected negative coefficient.

11 As in Table 1, each regression included the dependent variable, a constant, and the alternative indicator, with the regressions iterating over lags of zero through six months of the alternative indicators. The regression for China's imports also included the real effective exchange rate. Each regression for the dependent variables contains the same number of variables.

12 The global demand factor was calculated as the first principal component of an index derived from ocean dry bulk cargo freight rates (Kilian and Zhou 2018) and from data derived in the oil price decomposition published in the Federal Reserve Bank of New York's Oil Price Dynamics Report.

13 National Oceanic and Atmospheric Administration's National Centers for Environmental Information (formerly National Geophysical Data Center) 2010 Nighttime Lights Time Series (Version 4 DMSP-OLS; accessed September 2013), https://ngdc.noaa.gov/eog/dmsp/downloadV4composites.html.

14 The series include: industrial production of electricity, copper, aluminum, iron ore, pig iron, crude steel, steel products, cement, plated glass, refrigerators, air conditioners, and washing machines; retail sales above designated size; and apparent demand of crude and refined petroleum, which are computed as production minus exports plus imports. 


\section{REFERENCES}

Akinci, O., G. Benigno, and P. Pesenti. 2020. "The Impact of Foreign Slowdown on the U.S. Economy: An Open Economy DSGE Perspective." Federal Reserve Bank of New York Economic Policy Review 26, no. 4 (October): 98-112.

Biggs, M., T. Mayer, and A. Pick. 2009. "Credit and Economic Recovery: Demystifying the Phoenix Miracle." DNB Working Paper no. 218, July.

Chen, W., X. Chen, C.-T. Hsieh, and Z. Song. 2019. "A Forensic Examination of China's National Accounts." Brookings Papers on Economic Activity, Spring.

Clark, H., and J. Dawson. 2019. “Could Rising Household Debt Undercut China’s Economy?” Federal Reserve Bank of New York Liberty Street Economics, February 13.

Clark, H., M. Pinkovskiy, and X. Sala-i-Martin. 2017. "China’s GDP Growth May be Understated." NBER Working Paper no. 23323, April.

—. 2020. "China’s GDP Growth May Be Understated." China Economic Review 62 (August). https://doi.org/10.1016/j.chieco.2018.10.010.

Doll, C. N. H., J.-P. Muller, and J.G. Morley. 2006. "Mapping Regional Economic Activity from Nighttime Light Satellite Imagery.” ECOLOGICAL Economics 57, no. 1 (April): 75-92.

Federal Reserve Bank of New York. "Oil Price Dynamics Report." https://www.newyorkfed.org/research/policy/oil_price_dynamics_report.

Fernald, J., E. Hsu, and M. M. Spiegel. 2015. "Is China Fudging Its Figures? Evidence from Trading Partner Data.” Federal Reserve Bank of San Fransico Working Paper 2015-12, September.

—. 2019. "Is China Fudging Its GDP Figures? Evidence from Trading Partner Data." Federal Reserve Bank of San Francisco Working Paper 2019-19, August.

Goldman Sachs. 2017. "Understanding China’s Economic Statistics-Second Edition." Private client research.

Groen, J. J. J., and B. M. Nattinger. 2020. "Alternative Indicators for Chinese Economic Activity Using Sparse PLS Regression.” Federal Reserve Bank of New York Economic Policy Review 26, no. 4 (October): 39-68.

Henderson, V. J., A. Storeygard, and D. N. Weil. 2012. "Measuring Economic Growth from Outer Space." American Economic Review 102, no. 2 (April), 994-1028.

Higgins, M. 2020. “China's Growth Outlook: Is High-Income Status in Reach?” Federal Reserve Bank of New York Economic Policy Review 26, no. 4 (October): 69-97. 


\section{REFERENCES (CONTINUED)}

Holz, C. A. 2013. “The Quality of China's GDP Statistics." Stanford Center for International Development Working Paper no. 487, November.

Hu, Y., and J. Yao. 2019. "Illuminating Economic Growth." IMF Working Papers, no. 19/77, April.

Keidel, A. 2001. “China’s GDP Expenditure Accounts.” China Economic Review 12, no. 4 (December): 355-67.

Kerola, E. 2018. "In Search of Fluctations: Another Look at China's Incredibly Stable GDP Growth." Bank of Finland BOFIT Discussion Papers 23/2018.

Kilian, L., and X. Zhou. 2018. "Modeling Fluctuations in the Global Demand for Commodities." JournaL of International Money and Finance 88 (November): 54-78.

Maddison, A., and H. X. Wu. 2006. "China’s Economic Performance: How Fast Has GDP Grown; How Big Is It Compared with the USA?” Unpublished paper, University of Queensland.

Martinez, L. R. 2018. "How Much Should We Trust the Dictator's GDP Growth Estimates?" University of Chicago Harris School of Public Policy working paper, August.

Michalopoulos, S., and E. Papaioannou. 2013. "Precolonial Ethnic Institutions and Contemporary African Development." Econometrica 81, no. 1 (January), 113-52.

—. 2014. "National Institutions and Subnational Development in Africa." Quarterly Journal of ECONOMICs 129, no. 1 (February), 151-213.

Murray, L. 2016. "Beijing's Debt Problem Threatens to Go Off the Rails." The Australian Financial Review, May 11.

Orlik, T. 2012. Understanding China's Economic Indicators-Translating the Data into Investment Opportunities. Upper Saddle River, N. J.: FT Press.

Pettis, M. 2019. "What Is GDP in China?" China Financial Markets, January 16. Accessed April 8, 2018. https://carnegieendowment.org/chinafinancialmarkets/78138.

Pinkovskiy, M., and X. Sala-i-Martin. 2016a. "Lights, Camera,...Income! Illuminating the National Accounts-Household Surveys Debate." Quarterly Journal of Economics 131, no. 2 (May), 579-631.

—. 2016b. "Newer Need Not Be Better: Evaluating the Penn World Tables and the World Development Indicators Using Nighttime Lights." NBER Working Paper no. 22216, May. 


\section{REFERENCES (CONTINUED)}

Rawski, T. G. 2001. "What Is Happening to China’s GDP Statistics?" China Economic Review 12, no. 4: 347-54.

Reserve Bank of Australia. 2015. "Box A: China’s Industrial Sector." Statement on Monetary Policy, November. https://www.rba.gov.au/publications/smp/2015/nov/box-a-chinas-industrialsector.html\#fn1.

Rothman, A. 2019. "Has the China Collapse Finally Arrived?" Sinology, January 22. https://matthewsasia.com/perspectives-on-asia/sinology/article-1541/default.fs.

Shane, D. 2019. “How Bad Is China's Economic Slump? It’s Impossible to Tell." CNN Business, February 11. Accessed April 9, 2019. https://www.cnn.com/2019/02/11/business/china-economygrowth-data/index.html.

Sin, N. 2019. "Explainer: Why China's Inclusion in Global Bond Benchmarks Matters." Reuters, March 29. Accessed July 8, 2019. https://www.reuters.com/article/us-china-bonds-index-explainer/ explainer-why-chinas-inclusion-in-global-bond-benchmarks-matters-idUSKCN1RA0MU.

Stock, J., and M. Watson. 2012. "Disentangling the Channels of the 2007-2009 Recession." Brookings PAPERS On ECONOMic ACTIVITY, Spring: 81-141.

Wee, J.-L., and L. Yuan. 2018. "China Censors Bad Economic News amid Signs of Slower Growth." New York Times, September 28. https://www.nytimes.com/2018/09/28/business/china-censoreconomic-news.html.

Wigram Capital Advisors Limited. 2019. Section 1: Alternate Measures of Chinese Growth and Activity. Private client research.

Wu, H. X. 2014. "China’s Growth and Productivity Performance Debate Revisited-Accounting for China's Sources of Growth with a New Data Set." The Conference Board Economics Program Working Paper Series no. 14-01, January.

Wu, W. 2017. "Xi Joins Calls for More Control of Financial Risks." South China Morning Post, March 1.

Zhang, S., and L. Chen. 2018. "China's Stocks Rise Most in Two Months as Beijing Deemed To Be Adjusting Policies to Boost Domestic Growth.” South China Morning Post, April 24.

Zhang, X. 2016. "Key Article Signals Less Policy Easing in China: UBS.” Xinhua News Agency, May 10. 


\section{ECONOMIC POLICYREVIEW}

The Economic Policy Review is published by the Research and Statistics Group of the Federal Reserve Bank of New York. The views expressed are those of the individual authors and do not necessarily reflect the position of the Federal Reserve Bank of New York or the Federal Reserve System.

Series Editor: Julian di Giovanni. Editorial Staff: Robert Powell, Trevor Delaney, Maureen Egan, Anna Snider, and Peter Stevens. Design Staff: Theresa Izzillo, Laura Gharrity, and Jessica Iannuzzi.

Economic Policy Review articles may be reproduced for educational or training purposes, provided they are reprinted in full; include credit to the author(s), the publication, and the Bank; and include the publication's disclaimer.

(C2020 The Federal Reserve Bank of New York

www.newyorkfed.org/research

Follow us on Twitter: @NYFedResearch 